
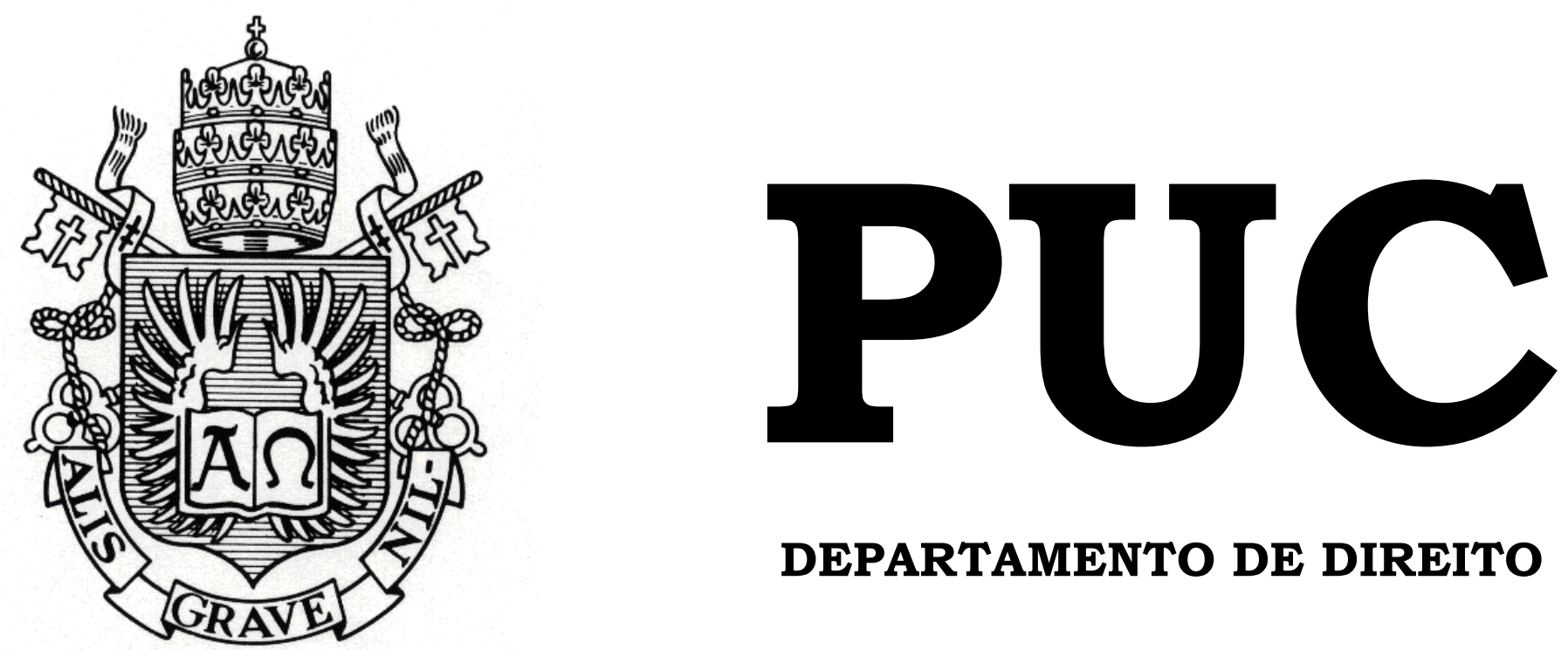

DEPARTAMENTO DE DIREITO

"Preso por ter cão, preso por não ter cão!": 0 Alienista e as Garantias Constitucionais no Brasil República do século XXI

por

Carolina Soares Vahia de Abreu

ORIENTADORA: Regina Coeli Lisboa Soares 2019.1

PONTIFÍCIA UNIVERSIDADE CATÓLICA DO RIO DE JANEIRO RUA MARQUÊS DE SÃO VICENTE, 225 - CEP 22453-900 RIO DE JANEIRO - BRASIL 


\title{
“Preso por ter cão, preso por não ter cão!": O Alienista e as Garantias Constitucionais no Brasil República do século XXI
}

\author{
por \\ Carolina Soares Vahia de Abreu
}

Monografia

apresentada

ao

Departamento de Direito da Pontifícia Universidade Católica do Rio de Janeiro (PUC-Rio) para a obtenção do Título de Bacharel em Direito.

Orientadora: Regina Coeli Lisboa Soares 
À minha mãe, que me deu a vida e apresentou suas várias possibilidades através da Literatura.

Ao Bruno, por escrever comigo nossa história de amor. 


\section{Agradecimentos}

Agradeço à minha mãe, Maria Lúcia, o grande encontro da minha vida, pela relação de amor, amizade, confiança, respeito e parceria que sempre cultivamos. Obrigada, mãe, por ter me dado a vida inúmeras vezes, não só através do parto, quando nasci, como nos momentos de alegria, que sempre compartilhamos juntas, e nas dificuldades, nas quais você nunca deixou faltar um livro sequer, e o mais importante, nunca me faltou o seu olhar atento e afetivo, o verdadeiro responsável pela pessoa que me torno a cada dia. A você, devo desde o abrir dos olhos até minha formação profissional e pessoal, e a certeza de que o amor eterno existe.

Agradeço ao Bruno, amor de quase uma década, por construir comigo a versão mais bonita de amor a dois que já experimentei. Pela companhia, amizade, confiança, e pelo melhor abraço do mundo. Apesar de não ter lido, até então, o conto que baseia este trabalho, prometeu que iria ler para compreender tudo o que escrevi. Para mim, o "eu te amo" mais bonito que foi dito sem palavras.

Agradeço à Aline, minha dupla de estudos e grande amiga, pelas trocas cotidianas, pelo amadurecimento ao longo desses cinco anos, pela relação de diálogo sincero que sempre prezamos. Por ser a pessoa que vale a pena dividir o sonho da formatura e compartilhar tantos outros.

Agradeço à Tati, amizade que devo à vida, pelas palavras sempre elogiosas que nunca economiza para os textos que escrevo, por sempre enaltecer as qualidades que diz que me pertencem, mas que saem mesmo dos seus olhos. Pelo sonho que compartilhamos da carreira pública, torço para que o destino aprenda com a nossa parceria, e nos seja generoso.

Agradeço aos meus professores de Língua Portuguesa do Colégio Santo Inácio, que me ensinaram a ler e amar Machado de Assis. 
Agradeço ao meu orientador de iniciação científica Fábio Leite, pela leitura sempre atenta dos meus textos, responsável pelo meu amadurecimento acadêmico e pessoal. Obrigada, Fábio, pelas conversas literárias, e pela forma especial que você conta a crônica da Tartaruga, do Rubem Braga.

Agradeço à Regina, minha orientadora e mestre querida, que aceitou o desafio de orientar este tema desde a nossa primeira conversa. Na memória, ficaram as citações de obras da literatura que encerravam as provas de Direito Constitucional, matéria em que fui sua aluna. No coração, o brilho nos olhos de quem ensina o que ama, e também o que não está escrito nos livros; ainda, a convicção de que "o correr da vida embrulha tudo (...) o que ela quer da gente é coragem" (Guimarães Rosa). 


\section{Resumo}

Sob a influência do Law and Literature Movement, o presente trabalho analisa o direito na literatura machadiana, especificamente no conto $O$ Alienista. A obra, apesar de publicada pela primeira vez no século XIX, permanece atual, visto que apresenta retratações caricatas da arbitrariedade e do poder, intrinsecamente relacionadas à legalidade, liberdade e ao interesse público, a dizer, direitos e garantias inseridos na Constituição Federal de 1988, que serão analisados em capítulos específicos. Assim, este trabalho monográfico visa expor em que medida o Direito apresenta mecanismos adequados no combate aos abusos perpetrados pelas autoridades, além de ressaltar o papel do advogado na luta diária para o funcionamento e coesão do estado democrático de direito.

PALAVRAS-CHAVE: Direito e literatura - Machado de Assis - legalidade liberdade de expressão - público e privado - norma jurídica - garantias fundamentais - Estado Democrático de Direito 


\section{Sumário}

Introdução

Capítulo 1 - Das Palavras às Obras: A Literatura como Caminho para

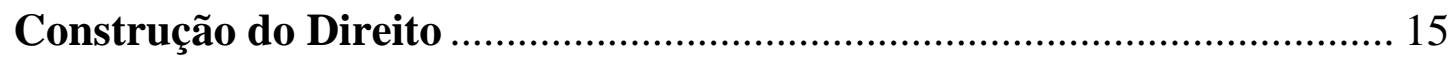

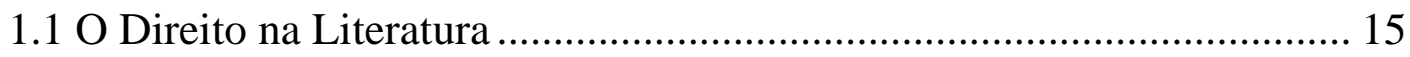

1.2 O Contexto Histórico da Obra e da Constituição de 1988 ....................... 19

1.3 A Supremacia da Constituição Federal e o Papel da Estrutura Jurídica no

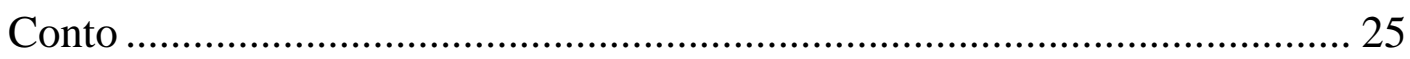

Capítulo 2 - O Delírio do Poder.................................................................. 29

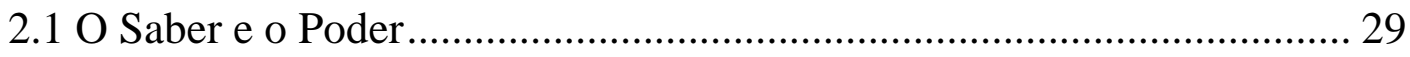

2.2 O Poder da Norma e o Abuso do Poder .................................................... 33

2.3 Os Direitos e as Garantias Fundamentais como Mecanismos para

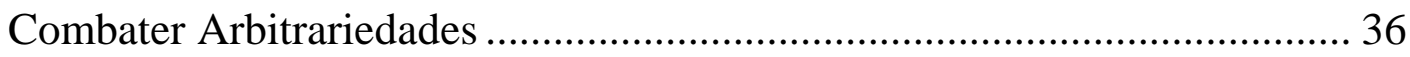

Capítulo 3 - Os Direitos e as Garantias Fundamentais na Constituição de 1988 e a Interpretação do Mundo das Leis

3.1 "Se um homem era avaro ou pródigo ia do mesmo modo para a Casa Verde; daí a alegação de que não havia regra para a completa sanidade mental" - A questão da legalidade. 40 
3.2 "O alienista, sabendo da extraordinária inconsistência das opiniões desse vereador, entendeu que era um caso patológico, e pediu-o" - A questão da liberdade de expressão.

3.3 "Desde que a Casa Verde começara a povoar-se tão extraordinariamente, viu crescerem-lhe os lucros (...); mas o interesse particular, dizia ele, deve ceder ao interesse público": A dicotomia entre o Público e o Privado......... 49

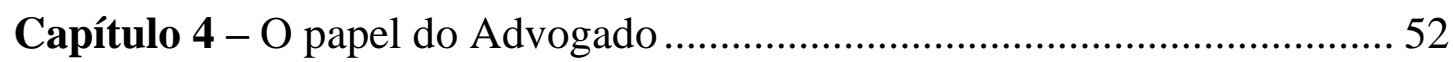

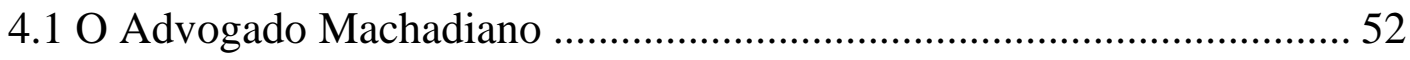

4.2 O Advogado como Protagonista na Defesa do Regime Democrático .... 54

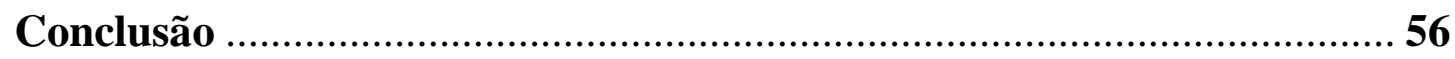

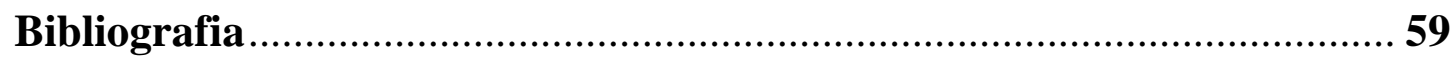




\section{Lista de Abreviações}

$\S$ - Parágrafo

Art. - Artigo

p. - Página

$\mathrm{n}^{\mathrm{o}}$ - Número

STF - Supremo Tribunal Federal 


\section{Introdução}

Com o intuito de sustentar a compreensão da presente monografia, parece interessante, neste primeiro momento, apresentar um resumo do conto

$O$ Alienista, destacando as passagens e as questões jurídicas que serão desenvolvidas ao longo do trabalho.

A obra inicia com o retorno do Dr. Simão Bacamarte, exímio médico, à cidade de Itaguaí, local em que se casa com D. Evarista, e se dedica à ciência, refletida no exercício de sua profissão, destacando-se como autoridade no exame das patologias cerebrais em uma época na qual a indiferença pelos portadores de sofrimento mental imperava. Neste cenário, o médico decidiu construir uma casa de Orates, que recebeu o nome de Casa Verde, para tratar os desatinados de Itaguaí, amparado pela autorização da Câmara dos Vereadores, que encontrou na ocasião oportunidade para instituir novo imposto destinado a custear o tratamento dos hipossuficientes acometidos pela loucura.

Uma vez construída, seu principal escopo, nas palavras de Simão Bacamarte, “(...) é estudar profundamente a loucura, os seus diversos graus, classificar-lhe os casos, descobrir enfim a causa do fenômeno e o remédio universal" (Gledson, 2015, p. 41). Este discurso simboliza a questão do saber, que posteriormente será entrelaçada com a figura do poder.

Adiante, Simão Bacamarte desenvolve uma nova teoria, segundo a qual a razão seria "o perfeito equilíbrio de todas as faculdades; fora daí insânia (...)” (p. 48), logo a compartilha com Crispim Soares, boticário da vila e seu amigo, nesta altura, um dos responsáveis pela administração da Casa Verde. Em resposta, o Boticário sugeriu a divulgação da ideia por matraca, que consiste em instrumento antigo utilizado para anunciar notícias, algum serviço ou produto. Embora o médico tenha refutado a ideia a princípio, é interessante analisar o papel das matracas descrito pelo narrador da obra: 
"Por exemplo, um dos vereadores (...) desfrutava a reputação de perfeito educador de cobras e macacos, e aliás nunca domesticara um só desses bichos; mas tinha o cuidado de fazer trabalhar a matraca todos os meses. E dizem as crônicas que algumas pessoas afirmavam ter visto cascavéis dançando no peito do vereador; afirmação perfeitamente falsa, mas só devida à absoluta confiança no sistema" (p. 48).

A absoluta confiança no sistema é tema da atualidade, responsável por grandes equívocos e até injustiças. O trecho citado propicia duas reflexões que abordam a ordem jurídica contemporânea, uma reforça a importância de institutos jurídicos capazes de questionar e corrigir eventuais falhas no sistema, e a título de exemplo destacam-se as garantias e os remédios constitucionais, ao passo que a outra revela a necessidade de buscar informações tidas como perfeitas a fim de evitar que se reproduza aquilo que se escuta sem qualquer estatuto de veracidade ou reflexão, de modo a assegurar a liberdade de pensamento.

A teoria desenvolvida pelo Alienista trouxe um período de medo e terror nos habitantes de Itaguaí, já que foram recolhidas à Casa Verde pessoas que, no diagnóstico do povo, não seriam acometidas pela loucura. Primeiro foi a vez do Costa, "um dos cidadãos mais estimados de Itaguai" (p. 49), em seguida, a tia do Costa, depois foi a vez de Mateus, o albardeiro, adiante foram recolhidas mais "vinte e tantas pessoas, - duas ou três de consideração" (p. 53), ato contínuo foram recolhidos Martim Brito, José Borges do Couto Leme, Chico das Cambraias, o escrivão Fabrício, Gil Bernardes e outros.

O medo diante da quantidade de recolhimentos sem aparente motivação fez nascer nos moradores de Itaguaí um enorme descontentamento, que anunciava a aproximação de uma rebelião. Contudo, antes de seu estopim, o barbeiro Porfírio propagou a ideia de mover "uma petição ao governo para que Simão Bacamarte fosse capturado e deportado" (p. 57). Neste trecho da obra, o narrador chama a atenção para o fato de que os lucros do barbeiro haviam crescido com a abertura da Casa Verde, apesar disso, o personagem 
afirmava que "o interesse particular (...) deve ceder ao interesse público. E acrescentava: - é preciso derrubar o tirano!” (p. 57).

O episódio suscita uma importante reflexão, que será desenvolvida no capítulo pertinente, a respeito da dicotomia entre o público e o privado.

Porfírio e cerca de trinta pessoas redigiram uma representação à Câmara dos Vereadores com o fim de obstar as arbitrariedades cometidas pelo Dr. Bacamarte. Em que pese o pedido não ter sido aceito, o senador Sebastião Freitas foi contrário à posição do presidente da Câmara, e "prometeu suspender qualquer ação, reservando-se o direito de pedir pelos meios legais a redução da Casa Verde” (p. 59). A fala do político traz à baila a questão da legalidade, isto é, a noção de que as ações devem ser amparadas pelo ordenamento jurídico, que representa a regra do jogo no estado democrático de direito.

A recusa dos vereadores em interferir na conduta do Alienista fez com que a insatisfação popular ganhasse corpo, inclusive, nome. Assim, a Revolta dos Canjicas, liderada por Porfírio, partiu em direção à residência do médico com a finalidade de demolir a Casa Verde ou, ao menos, libertar aqueles que lá se encontravam. Após nova recusa do pleito, diretamente de Simão Bacamarte, os revoltosos estavam decididos a derrubar a instituição, quando foram interrompidos pela força pública, descrita na figura do corpo de dragões.

Durante o confronto, ocorreu um fato inesperado: um terço dos dragões juntou-se ao lado da revolta, o que criou desconforto nos soldados representantes da legalidade, que não queriam atacar seus companheiros. Foi assim que a revolução saiu vitoriosa e seguiu para a Câmara dos Vereadores, que não resistiu e entregou-se, de modo a permitir que Porfirio assumisse o governo com a anuência do povo.

No dia seguinte, o barbeiro saiu da Câmara rumo à casa do Alienista. Ao contrário do prometido, Porfírio desistiu de demolir a Casa Verde para propor ao médico que este se unisse ao governo, de modo a atrair a confiança 
dos "principais da vila" (p. 67), e em contrapartida, a nova administração não interferiria nas questões científicas.

O médico não apenas renuiu a proposta, como também recolheu apoiadores do governo à Casa Verde, o que gerou maior indignação do povo. Nesta oportunidade, João Pina, outro barbeiro de Itaguaí, congregou a população a seu favor e derrubou Porfírio, de modo a assumir o governo, que não demorou a ser deposto pelas tropas enviadas pelo vice-rei, sendo a ordem restabelecida.

Neste cenário, a Câmara dos Vereadores retomou suas atividades, tendo consentido que Sebastião Freitas fosse recolhido ao hospício, a pedido do Alienista, que "sabendo da extraordinária inconsistência das opiniões desse vereador, entendeu que era um caso patológico, e pediu-o" (p. 69). Este trecho da obra, mais uma vez, aborda a questão da liberdade de expressão, tema que será tratado em capítulo específico.

A esta altura, Porfírio, o presidente da Câmara dos Vereadores, Crispim Soares, entre outros itaguaienses, foram levados ao hospício, abrindo caminho para recolhimentos desenfreados, a ponto de o narrador do conto concluir que "Se um homem era avaro ou pródigo ia do mesmo modo para a Casa Verde; daí a alegação de que não havia regra para a completa sanidade mental" (p. 69). A afirmação reflete a questão da legalidade, que pode ser entendida como a importância de normas bem delimitadas, que servem de instrumento para impedir arbitrariedades e garantir a segurança jurídica, que também será objeto de análise neste trabalho.

O número abundante de membros da população que se encontrava na Casa Verde levou Simão Bacamarte a rever sua teoria das moléstias cerebrais. Desta análise, concluiu que o perfeito equilíbrio das faculdades mentais seria irregular, ou seja, a retidão de caráter e a coerência nas condutas seriam características anormais nas pessoas. A constatação do médico fez com que ele 
redigisse ofício à Câmara anunciando que libertaria todos que estavam agasalhados a serviço da ciência a fim de fazer valer sua nova suposição.

Em resposta, a Câmara decidiu legislar sobre a pretensão do médico, concedendo autorização para o recolhimento daqueles que apresentassem o perfeito equilíbrio das faculdades, com algumas ressalvas - a permissão seria provisória, de modo que a Câmara poderia fechar a instituição, a qualquer momento, por motivos de ordem pública. Na oportunidade, foi redigida cláusula que impedia o recolhimento dos vereadores à casa dos alienados, sendo certo que o vereador Galvão foi o único a votar contra esta exceção, fato que, de acordo com os novos critérios, o levou para a Casa Verde.

Sob a égide dessa metodologia, quem conseguiu escapar do hospício foi o advogado Salustiano. Preliminarmente, o Alienista reconheceu no causídico um conjunto de qualidades morais e mentais, e, por esse motivo, esteve prestes a recolhê-lo a Casa Verde. No entanto, quando soube que conseguiu absolver um cliente acusado de ter falsificado testamento, fazendo com que o réu recebesse a herança pleiteada, mudou de ideia, pois a situação evidenciava o perfeito desequilíbrio mental do advogado. Este trecho da narrativa anuncia a figura do advogado Machadiano, retratado com posturas questionáveis e em tom irônico, objeto que será desenvolvido no último capítulo deste trabalho.

Insatisfeitos com o retorno dos recolhimentos e desenganados da aparente legalidade (p. 76), as principais figuras da vila recorreram ao Porfírio, oferecendo apoio, dinheiro e influência em troca de outro movimento contra o Alienista e a Câmara dos Vereadores. O barbeiro recusou, afirmando que a revolta perpetrada havia sido um equívoco, tendo reconhecido seu erro. Quando Simão Bacamarte tomou conhecimento da maestria moral do barbeiro, ordenou que fosse novamente recolhido, afinal, se enquadrava nos aspectos da nova teoria. Daí surge a frase que intitula este trabalho "- Preso por ter cão, preso por não ter cão! exclamou o infeliz" (p. 76). 
Abrigados os supostos loucos, o Alienista iniciou o sistema terapêutico para tratá-los. Começou dividindo-os por classes, de acordo com a "perfeição moral que em cada um deles excedia (...)” (p. 77) para enfrentar a qualidade predominante. Passados cinco meses e meio todos estavam recuperados, e foram devolvidos à sociedade. Após longa reflexão, o médico concluiu que as pessoas que acabava de curar possuíam o cérebro tão desequilibrado como as demais que antes habitaram a instituição. Ao olhar para si, Simão Bacamarte encontrou os aspectos do perfeito equilíbrio mental e moral, e não hesitou recolheu-se à Casa Verde, local onde permaneceu até sua morte. 


\section{Capítulo I - Das palavras às Obras: A Literatura como Caminho para Construção do Direito}

\subsection{O Direito na Literatura}

O caminho percorrido pelo Direito que vai ao encontro da Literatura é capaz de proporcionar uma nova interpretação dos institutos jurídicos, e consequentemente, da dinâmica social que marca uma determinada sociedade. Assim, distante da pretensão de promover a reinvenção do Direito, a Literatura se propõe, inicialmente, a recontar o universo jurídico (Schwartz, 2006, p. 45).

Neste contexto, é interessante observar que tanto o Direito quanto a Literatura são fundados pela palavra, já que também as "leis nascem das letras": "ambos são textos (...), reclamam uma atividade que apure o sentido de suas construções, evidenciando a relação entre o construtor/legislador e o destinatário/cidadão da norma jurídica” (p. 50).

A partir deste ponto em comum, surgem dimensões de análise da ciência jurídica: em contraposição à teoria analítica do Direito, objeto de estudo dominante das Universidades, surge a perspectiva do direito narrado. Enquanto a primeira concepção consiste na análise de fatos empíricos e posterior aplicação de normas, de método positivista, a teoria do direito contado "preocupa-se antes com a "coerência narrativa" do raciocínio, $e$ evidencia a importância da interpretação dos textos e da natureza argumentativa das discussões jurídicas (...)” (Ost, François, 2007, p. 44).

Diante do contraponto apresentado, François Ost destaca que o direito positivo, como todo formalismo, encontra problemas no interior do sistema. Para ilustrar a discussão, o autor exemplifica a tentativa de Hans Kelsen, o grande nome do positivismo jurídico, encontrar resposta para o que garante a validade (jurídica) da norma jurídica superior. A solução encontrada por Kelsen, em sua Teoria Pura do Direito, é a criação da "norma fundamental" 
como condição de validade do ordenamento jurídico, representando assim uma ficção jurídica (p. 42).

Neste sentido, a "teoria pura" tem como seu pilar estrutural uma ficção, de modo que está diretamente relacionada à ideia de uma "narrativa fundadora", nos termos de Ost. Outro exemplo no qual é possível perceber que a Literatura caminha ao lado do Direito encontra-se na teoria segundo a qual a origem do estado de direito remonta à fábula da saída do estado de natureza, tema abordado por Hobbes, Locke e Rousseau, desde o século XVII (p. 42).

Em razão do evidente diálogo entre o Direito e a Literatura, no que diz respeito à origem histórica deste parâmetro epistemológico, ensina Germano Schwartz que o movimento Law and Literature ganhou destaque nos anos 80 nos Estados Unidos, sendo responsável pela sistematização e organização do novo método de estudo, ainda pouco acolhido no Brasil. Como fundamento primordial da disciplina, o autor sustenta:

"Com efeito, um dos grandes objetivos dessa proposta é encontrar, na Literatura, pontos de apoio que forneçam ao Direito (e à Constituição) compreensões necessárias - a serem amealhadas e (re)processadas por sua lógica funcional - sobre o bem e o mal, o justo e o injusto e o legal e o ilegal. Dessa maneira, a Literatura poderá conduzir o Direito (Constitucional) a um aprofundamento de seus valores e de suas decisões, mormente porque baseadas em um texto (direito positivado)" (Schwartz, 2006, p. 52).

Com o escopo de sistematizar o estudo fruto da relação interdisciplinar entre Direito e Literatura, foram criadas três categorias, com focos distintos, pelo Law and Literature Movement. São elas: o Direito na Literatura, o Direito como Literatura e o Direito da Literatura. O presente trabalho se dedica a uma abordagem que se enquadra no primeiro grupo. Mesmo assim, faz-se necessário entender os traços que ensejam a distinção entre tais categorias.

Segundo Schwartz, o estudo do Direito na Literatura refere-se à área que investiga as configurações sob as quais o Direito é representado nas narrativas literárias. Assim, entende o autor que por meio da influência 
recíproca entre as duas formas de compreender o mundo surge a "possibilidade da construção de ensino e de aplicabilidade de um novo Direito a partir de paradigmas mais conectados com a sociedade na qual se insere" (p. 57). Afinado com esta ideia, Ost delimita a área como aquela que aborda a forma como a literatura trata questões de justiça e poder, subjacentes nas normas (Ost, 2007, p. 48).

Em consonância com esta proposta, Eliane Junqueira sustenta que na medida em que os trabalhos de ficção abordam questões jurídicas, o conhecimento de tais obras por parte do estudante, bem como do profissional, pode auxiliar no contato com determinadas experiências legais (Junqueira, 1998, p. 24).

Em divergência da primeira categoria, o Direito como Literatura propõe a leitura dos institutos jurídicos através das lentes de um leitor por excelência. Explica-se: os atos jurídicos, as peças processuais e as fases do processo são analisados como atos literários. Estuda-se, portanto, os institutos jurídicos com o método da análise literária (Ost, 2007, p. 48). Como esclarece Schwartz:

\footnotetext{
“(...) os atos escritos do sistema jurídico são formas de contar e de repassar uma história/estória, sendo perfeitamente possível conceber, por exemplo, uma sentença como uma peça com personagens, início, enredo e fim. Ainda nessa esteira de raciocínio, a citação de jurisprudência e precedentes em uma petição é um relato intercalado, adaptado à necessidade de um suporte jurídico (Schwartz, 2006, p. 58)”.
}

Assim, o processo é visto como "um universo de histórias narradas pelas partes e que buscam o convencimento de um terceiro (leitor): o juiz" ( $\mathrm{p}$. 59), o que revela o aspecto narrativo como ponto em comum de ambas as áreas do conhecimento.

No âmbito deste estudo, a linguagem exige atenção especial. Como ensina Eliane Botelho, as palavras empregadas no mundo jurídico garantem um poder simbólico, tendo em vista que "a autoridade desses textos provém, 
em grande parte, de sua forma estética, cultivada pelos experts e valorizada pelos leigos" (Junqueira, 1998, p. 22).

A respeito da linguagem, Michel Foucault aborda a problemática de sua materialidade:

\begin{abstract}
"Se considerarmos a linguagem como uma série de fatos tendo um determinado estatuto de materialidade, essa linguagem é um abuso de poder pelo fato de podermos usá-la de uma determinada maneira, tão obscura, que vem impor-se à pessoa a quem é dirigida, do exterior, criando problemas sem solução, seja de compreensão, de reutilização, de retorsão, de respostas, de críticas, etc. (Foucault, 2005, p. 158)".
\end{abstract}

De igual modo, é possível afirmar que a palavra que cria barreiras para o entendimento é a mesma que permite diferentes interpretações e novas formas de leituras do texto, conforme o contexto histórico em que o leitor se encontra. A partir da reflexão proposta por Foucault, e diante da análise do Direito enquanto prática social, conclui-se que se trata de domínio de saber que transparece novos objetos, conceitos, técnicas e, também, novas formas de sujeitos e de sujeitos de conhecimento (Foucault, 2005, p. 8), e tudo isso pode ser apreciado sob o esteio da Literatura.

Há, ainda, o estudo do Direito da Literatura, que se restringe ao exame das normas jurídicas que resguardam a atividade literária, de modo a abarcar as relações jurídicas do exercício literário e as normas que regulam a criação e a difusão da obra literária, bem como os direitos a ela atrelados (Ost, 2007, p. $61)$.

Entre as categorias apresentadas, a análise do Direito sob a perspectiva literária permite uma releitura do mundo jurídico capaz de sensibilizar o intérprete, que harmoniza seu conhecimento técnico ao sentimento de humanidade (p. 75). Através de recursos da língua, torna-se possível criar estruturas narrativas capazes de produzir reflexão crítica aos leitores. 


\subsection{O Contexto Histórico da Obra e da Constituição de 1988}

De acordo com Ingo Sarlet, a história constitucional brasileira tem início com a emancipação de Portugal, momento que o país se constitui como Estado e Nação politicamente independente. Neste contexto, a primeira Assembleia Nacional Constituinte do Brasil foi instalada no dia 3 de maio de 1823, e realizada sob a presidência do Bispo Capelão-Mor, D. José Caetano da Silva Coutinho, menos de um ano após a declaração de independência de D. Pedro I (Sarlet, 2016, p. 223). Observa-se, assim, que o início da história do constitucionalismo brasileiro é marcado pela influência da Igreja católica.

$\mathrm{Na}$ contramão do ufanismo democrático-liberal que vigorava à época, demorou apenas seis meses desde sua instauração para que D. Pedro I dissolvesse a Assembleia Constituinte, em razão da insatisfação da limitação de seus poderes imperiais, e convocasse um Conselho de Estado integrado por dez membros nomeados por ele para elaborar um projeto de Constituição, fato responsável pela outorga do primeiro texto constitucional brasileiro: a Constituição Imperial de 1824 (Sarlet, 2016, p. 224).

Em consonância com os interesses do Imperador, a primeira carta constitucional instituiu um governo monárquico e representativo. No âmbito da divisão dos poderes, o poder moderador era o quarto poder e a chave da organização política, exercido privativamente por D. Pedro I para resguardar a manutenção da independência, harmonia e equilíbrio dos demais poderes políticos (Silva, 2015, p. 77).

Apenas em meados de 1834, através da primeira reforma constitucional impulsionada pela Câmara Baixa, que atualmente corresponde à Câmara dos Deputados, a constituição imperial "começou a se legitimar materialmente, como texto constitucional que concedia liberdades e limitava poderes" (Sarlet, 2016, p. 224), através de ações como a extinção do Conselho de Estado, a 
institucionalização da Regência una e a criação de Assembleias Legislativas Provinciais.

No que tange especificamente aos direitos e garantias individuais, a Carta Imperial de 1824 continha, entre os direitos sociais, o direito aos socorros públicos, que hoje corresponderia à assistência social em saúde, além da instrução primária gratuita a todos os cidadãos.

Em contraposição a tais direitos, sabe-se que durante o período de vigência dessa constituição vigoraram os privilégios da nobreza, o voto censitário e o regime escravocrata. Ainda, como marco do período da Regência, o país foi palco de instabilidades políticas e sociais, protagonizados por movimentos liberais, contrários à ordem monárquica (p. 226).

Como era de se esperar, em razão do influxo da Igreja sobre o Estado, a constituição imperial determinou o catolicismo como a religião oficial estatal. Assim, o regime de padroado pautava as relações entre a Igreja e a Coroa, de modo que os membros do corpo eclesiástico eram pagos pelo Estado, comparados a funcionários públicos, e deviam total obediência ao Imperador (Pereira \& Koshiba, 2003, p. 220). Sabe-se, todavia, que a relação entre o Estado e a Igreja nem sempre foi marcada pela paz divina, de modo que no avançar da história os atritos e rupturas ganharam novos contornos.

$\mathrm{Na}$ ficção, ensina Ivan Teixeira que O Alienista representa a "caricatura específica dos desentendimentos do clero com o estado, ocorridos no Brasil entre 1872 e 1875" (Teixeira, 2008, p.158). Já no primeiro capítulo da obra, quando Simão Bacamarte, médico respeitado de Itaguaí, decide tratar os loucos da cidade, é perceptível a tensão entre tais estruturas de poder. Desconfiado, o padre Lopes, vigário da cidade, adverte a mulher do doutor, D. Evarista, que o hábito de estudar muito virava o juízo. Em sua interpretação, Teixeira alerta para o fato de que as insinuações contra a Igreja presentes na obra não consistiriam em expor sua disposição para o mando, mas em evidenciar os artifícios empregados para dissimular essa pretensão (p. 158). 
De volta à realidade, como consequência do conjunto "de causas políticas, econômicas e socioculturais, que vinham se materializando ao longo do Segundo Reinado" (Sarlet, 2016, p. 227), no dia 15 de novembro de 1889 foi proclamada a primeira República Federativa do Brasil. O novo regime exigia uma nova constituição, cujo anteprojeto foi elaborado pela "Comissão dos Cinco", presidida por Joaquim Saldanha Marinho, passou pela redação final de Rui Barbosa para, em seguida, ser submetida à Assembleia Constituinte instalada um ano após a proclamação da república (p. 227).

O resultado deste processo foi a promulgação da Constituição de 1891, que consagrou o estado federal com a consequente autonomia para os estadosmembros, a separação de poderes, bem como o abandono do poder moderador, a periodicidade dos mandatos políticos, o sistema presidencialista de governo e a adoção de um estado laico, consubstanciado na separação do Estado e da Igreja. No âmbito das garantias fundamentais, nasce a figura do habeas corpus, principal ação para defesa dos direitos individuais diante das ilegalidades e abuso do poder perpetrados pelo Estado. Paralelamente, os direitos sociais presentes na Carta Imperial foram excluídos da Constituição de 1891 (p. 228229).

Entre esses dois capítulos da história constitucional brasileira foi publicado "O Alienista", de Machado de Assis, na revista "A Estação", entre outubro de 1881 e março de 1882. Sabe-se que a colaboração do escritor na respectiva seção literária, criada em 1879, foi intensa até 1891(Teixeira, 2008, p. 152). A respeito da publicação, é importante observar que:

\footnotetext{
"Sendo uma revista de moda feminina, A Estação deve ser classificada como instituição de cultura, no sentido intrínseco do termo, pois, ao falar de roupa e agasalho, produzia igualmente noções essenciais sobre gesto social, intimidade doméstica, moralidade, lazer, saúde, higiene e religião [...] Sendo, obviamente, uma publicação destinada às camadas ricas e letradas do país, havia também uma seção de teatro, de crítica literária, de poesia, de crônica, de romance e de contos (Teixeira, 2008, p. 152)".
} 
Como observa Teixeira, a obra retrata, por meio da sátira, a cidade de Itaguaí como "metáfora dos costumes do Rio de Janeiro oitocentista", através de caricaturas de autoridades, seja ela religiosa, médica, política e, inclusive, o desejo de autoridade popular. Em outras palavras, a Igreja, a ciência, a câmara dos vereadores e o povo, como as instâncias responsáveis pela construção do mundo, são alvos de representação caricata no texto (Teixeira, 2008, p. 150).

Entre as diversas representações contidas na obra, Teixeira sustenta que é possível identificar a figura de Simão Bacamarte com a imagem imperial de D. Pedro II, associado ao cenário do Segundo Reinado brasileiro. Tanto o imperador quanto o personagem foram impulsionados pela racionalidade e ciência, na medida em que instalaram hospícios nas respectivas cidades (p. 151). A narrativa, inclusive, inicia tratando de como Itaguaí ganhou sua primeira casa de Orates, a Casa Verde.

As caricaturas ganham maior relevo na medida em que se verifica o descaso dos vereadores de Itaguaí com a população. Alheios ao interesse público e com a fama de "não fazer caso dos dementes" (Gledson, 2015, p. 39), aprovaram as aspirações de Simão Bacamarte não sem antes instituir um novo tributo, instrumento por excelência capaz de angariar recursos para os cofres públicos.

"Dali foi à câmara, onde os vereadores debatiam a proposta e, defendeu-a com tanta eloquência, que a maioria resolveu autorizá-lo ao que pedira, votando ao mesmo tempo um imposto destinado a subsidiar o tratamento, alojamento e mantimento dos doidos pobres. A matéria do imposto não foi fácil achá-la; tudo estava tributado em Itaguaí. Depois de longos estudos, assentou-se em permitir o uso de dois penachos nos cavalos dos enterros (Gledson, 2015, p. 40)".

Neste sentido, os vereadores refletem o panorama da política brasileira. Como pilar da história social humana, o povo é refletido pela figura do barbeiro Porfírio, que liderou a rebelião popular voltada, no primeiro 
momento, para destruir a Casa Verde, diante dos recolhimentos arbitrários realizados pelo célebre Doutor da cidade (p. 151).

Paralelamente ao contexto temporal da obra, sabe-se que o período Regencial, que compreende os anos de 1831 até 1840, foi marcado pela ameaça à união do Império brasileiro, em razão das revoltas de inspiração liberal. Entre elas, a Balaiada, movimento político originado no Maranhão, a Revolta da Sabinada, movimento separatista que teve como palco a cidade de Salvador, a Cabanagem, insurreição popular ocorrida no Pará, bem como a Praieira, situada em Pernambuco (Sarlet, 2010, p. 226).

Nos termos de Teixeira, a sátira de $O$ Alienista prefere a denúncia conceitual à acusação direta de pessoas ou instituições (p. 152). Assim, a Revolta dos Canjicas ironiza aspectos comuns aos discursos que se formaram a partir dos movimentos populares do Segundo Reinado, com ênfase especial na questão das mortes "em nome de contingências frágeis e passageiras, que, não obstante, se apresentam aos revoltosos e ao governo como verdades essenciais e inegociáveis" (p. 165). Dessa forma, a revolução liderada pelo barbeiro Porfírio era uma abstração, e mesmo assim conseguiu derrubar a câmara de vereadores e resultar na morte de onze pessoas, somadas as vinte e cinco feridas.

Posteriormente, houve a tentativa de acordo com o padre Lopes sem qualquer sucesso, e contrariando o propósito inicial da revolta popular, o barbeiro tentou se aliar a Simão Bacamarte, que o recolheu à Casa Verde. É curioso perceber que, como observa Teixeira, não é o fato de Porfírio ter liderado o movimento o responsável pela decretação de sua insanidade, mas a circunstância de ter provocado mortes e pessoas feridas.

O episódio revela o olhar Machadiano sobre os movimentos sem orientação conceitual rígida e programa de ação (p. 166). Nas entrelinhas, o autor não desqualifica a noção de revolução política, mas entende que só se 
justifica pela necessidade dos motivos, que devem ser pautados pela razão, único caminho capaz de legitimar o poder (p. 167).

Justamente sob a égide da razão, anos mais tarde, foi elaborada a Constituição de 1988, para substituir aquela outorgada à época da ditadura militar, reformada em 1969. A atual Constituição do Brasil foi fruto de uma intensa participação popular e de um processo de deliberação inédito na história do país. Como relata Adriano Pilatti,

“(...) a Assembleia Nacional Constituinte de 1987-1988 (ANC) foi palco de grandes conflitos de interesse e opinião que haviam permanecido latentes, irresolutos ou agravados, durante os anos de repressão [...] Ali aconteceu um processo decisório caracterizado pelo dissenso, pela intensa e permanente mobilização de atores coletivos internos e externos, por votações altamente polarizadas e, ao mesmo tempo - sobretudo em sua fase final -, por uma atividade igualmente intensa e incessante de busca de acordos entre as lideranças das diferentes forças em choque" (Pilatti, 2008, p. 1).

Como ensina Sarlet, antes da elaboração da Constituição Cidadã, o presidente José Sarney criou uma Comissão Provisória de Estudos Constitucionais, que recebeu o nome de "Comissão dos Notáveis", composta por cinquenta personalidades das áreas econômica, política, social e cultural, além de juristas, de ideologias distintas, com o objetivo de elaborar o anteprojeto constitucional. Além disso, a sociedade civil também se fez presente, por meio das audiências públicas realizadas no âmbito das subcomissões temáticas e pela apresentação de emendas. O resultado desse encontro foi um texto de tom progressista, enlaçado com a ideia de Estado Social e Democrático de Direito (p. 239-241).

A nova ordem constitucional assumiu o compromisso idealizado, tendo sido promulgada no dia 05.10.1988, e pela leitura de seu Preâmbulo, bem como do Título dos Princípios Fundamentais, salta aos olhos o desvelo com o ser humano e o desenvolvimento de sua personalidade. Nesta seara, Sarlet destaca o Título dos Direitos e Garantias Fundamentais, que abrange os 
direitos e garantias individuais associados à ideia de liberdade, direitos sociais, incluindo os direitos trabalhistas, além do direito de nacionalidade e dos direitos políticos. Entre os instrumentos que reforçam a importância destes direitos estão o art. $5^{\circ}, \S 1^{\circ}$, que determina a aplicação imediata das normas de direitos fundamentais, somada à proteção ao conteúdo essencial do texto, disposta no art. $60, \S 4^{\circ}$, que estabelece as cláusulas pétreas (p. 244-245).

Na trajetória descrita, a ideia de Constituição passou por alterações. De acordo com Luís Roberto Barroso, o constitucionalismo liberal cedeu espaço para o constitucionalismo social, o que se reflete em 1988. Isso significa que os direitos voltados à realização da igualdade material ganharam destaque no novo texto, fazendo com que ocorresse uma ampliação do papel do Estado nas esferas econômica e social (Barroso, 2009, p. 84).

\subsection{A Supremacia da Constituição Federal e o Papel da Estrutura Jurídica no Conto}

Com a redemocratização do Brasil e a promulgação da nova ordem constitucional buscou-se a efetividade do texto por meio da força normativa da Constituição de 1988 (Barroso, 2009, p. 85). Para melhor compreensão desta afirmativa, faz-se necessário o desenvolvimento do tema.

De acordo com Gomes Canotilho, as questões jurídico-constitucionais devem ser analisadas de modo a priorizar as soluções que possibilitam a atualização normativa da constituição e, simultaneamente, garantam sua eficácia e permanência (Canotilho, 2010, p. 1226).

A respeito da questão, Konrad Hesse assegura que a essência da norma constitucional encontra-se na sua vigência. Essa pretensão de eficácia consiste na verificação de que a situação regulada pela Constituição se materializa na realidade. Para que isso seja concretizado, a norma jurídica deve contemplar as condições naturais, econômicas, sociais, além da estrutura axiológica daquela 
sociedade, de modo que a Constituição seja a expressão do ser e do dever ser (Hesse, 1991, p. 14-15).

Dessa forma, entende o autor que a Constituição adquire força normativa na medida em que realiza a pretensão de eficácia, e vai além ao sustentar que "somente a Constituição que se vincule a uma situação histórica concreta e suas condicionantes, dotada de uma ordenação jurídica orientada pelos parâmetros da razão, pode, efetivamente desenvolver-se" (p. 16).

Neste contexto, para que os princípios fundamentais obtenham força normativa, em um mundo marcado por constantes alterações político-sociais, faz-se necessário que incorporem o "estado espiritual de seu tempo", para que sejam acolhidos e tenham a seu favor a defesa da consciência geral. Além disso, tornam-se imprescindíveis para a existência dos direitos fundamentais, os deveres (p. 20-21).

O que garante a posição destacada de tais direitos, como ensina Sarlet, é o Princípio da Supremacia da Constituição (p. 215). No mesmo sentido, Barroso ressalta que a supremacia constitucional é o postulado que serve de base para o direito constitucional contemporâneo. Esclarece, ainda, que em razão de sua origem e natureza, as normas constitucionais ocupam posição hierárquica superior em relação às demais normas que compõem o sistema jurídico. A consequência disso é que os atos jurídicos incompatíveis com essas normas e princípios serão inválidos (p. 83-84). Em outras palavras, como conclui Sarlet, os direitos fundamentais são critérios de medida para todos os atos normativos (p. 215).

Paralelamente a letra da lei, também se faz necessário observar " $a$ pena da galhofa e a tinta da melancolia" (Assis, 2012, p. 11) que reconta o cotidiano. Assim, é interessante analisar o papel da estrutura jurídica na obra $\mathrm{O}$ Alienista, de Machado de Assis.

De plano, salta aos olhos o fato de que a sátira existente no conto transcende os limites espaciais e temporais delimitados pelo narrador. Sob o 
pretexto da loucura e a disputa pelo controle social, a história tem como elemento estruturante o objeto que pouco aparece traduzido em palavras, mas que se percebe nas entrelinhas: o ordenamento jurídico e seus instrumentos de legitimação das ações (Teixeira, 2008, p 162). Como bem observou Teixeira, "o texto sugere, de fato, que Itaguaí é um pouco mais do que Itaguaí. Equipara-se ao universo" (p. 162).

$\mathrm{O}$ que se materializa através das arbitrariedades dos recolhimentos da população de Itaguaí à Casa Verde é a construção de uma nova lei - a lei da razão, criada pelo próprio Alienista. Assim, no primeiro momento, a razão consistiria no "perfeito equilíbrio de todas as faculdades" (Gledson, 2015, p. 48).

Quando Simão Bacamarte recolhe o Coelho, sujeito de "excelente caráter" (p. 57), mais uma vez a estrutura jurídica se faz presente e legitima as ações dos personagens do conto, de modo que um grupo de pessoas do povo se junta ao barbeiro Porfírio para levar uma representação à Câmara, que sob o argumento de que a ciência não poderia ser alterada por votação administrativa, nem por movimentos de rua, não aceita o documento.

Outro episódio marcado por instrumentos jurídicos aparece quando o alienista envia um ofício à Câmara, no qual reconhece que a doutrina utilizada por ele até o momento estava equivocada e informa que soltará todos os reclusos da Casa Verde, e recolherá aqueles que se enquadram nos novos critérios. Em resposta, a Câmara faz uma ressalva: o médico estaria autorizado a agasalhar na instituição aqueles que se enquadrassem no novo parâmetro, no entanto, fica estabelecida uma cláusula no sentido de que os vereadores não poderiam ser recolhidos junto aos alienados (p. 73).

Em uma frase que revela o alcance do direito no conto ora analisado, Teixeira conclui que "(...) essa modalidade de texto costuma ser apreciada como exercício dos direitos e deveres da cidadania" (Teixeira, 2008, p. 152). Se por um lado a Obra contribui para a crítica do universo jurídico, por outro 
acentua a importância de uma ordem constitucional que apresente direitos e garantias fundamentais que estejam em consonância com as necessidades sociais, único caminho possível para o ideal do Estado Democrático de Direito. 


\section{Capítulo II - O Delírio do Poder}

\subsection{O Saber e o Poder}

No âmbito da relação entre o saber e o poder destaca-se o pensamento do filósofo francês Michel Foucault. Acerca do saber, ganha relevo a primeira conferência que compõe o livro "A verdade e as formas jurídicas", na qual o autor dialoga com a obra de Nietzsche a respeito do conhecimento. Foucault ensina que o filósofo alemão acreditava que o conhecimento não estava inscrito na natureza humana, mas seria o resultado do confronto entre os instintos humanos. Por esta razão, seria possível afirmar que o conhecimento foi inventado (Foucault, 2005, p. 16), afinal, não nasceu com o homem, mas a partir dele.

Ainda em interlocução com o pensamento de Nietzsche, Foucault afirma que para saber o que é o conhecimento é necessário compreender as relações de poder (p. 23). Para ele, o sujeito de conhecimento e as relações de verdade são formados a partir das condições políticas e econômicas:

"Só pode haver certos tipos de sujeito de conhecimento, certas ordens de verdade, certos domínios de saber a partir de condições políticas que são o solo em que se formam o sujeito, os domínios de saber e as relações com a verdade" (p. 27).

Em outro momento, em sua Arqueologia do Saber, Foucault define de forma pormenorizada que o saber é:

“(...) aquilo de que podemos falar em uma prática discursiva que se encontra assim especificada: o domínio constituído pelos diferentes objetos que irão adquirir ou não um status científico (...) um saber é, também, o espaço em que o sujeito pode tomar posição para falar dos objetos de que se ocupa em seu discurso (...)" (Foucault, 2017, p. 219-220).

A partir deste conceito, entende-se que um saber, dentre outras definições, pode ser construído com base no discurso de um sujeito que detém 
o conhecimento, e, consequentemente, a legitimidade para praticá-lo, a exemplo de um médico que através de observação, interrogação, registro e decisão forma o saber da medicina clínica (p. 220).

Roberto Machado, escritor e professor de Filosofia da Universidade Federal do Rio de Janeiro, ao escrever o livro A ciência e o saber, chama atenção para o fato de que a questão central das novas pesquisas de Foucault é o poder e sua importância para a constituição dos saberes (Machado, 1982, p. 188). Em outras palavras, o poder se apresenta como instrumento capaz de explicar a produção dos saberes.

Neste contexto, Foucault percebe que o poder não se manifesta apenas através da figura do Estado, de modo que não existe um único órgão de poder, e sim poderes, articulados de formas variadas, tanto em nível local como regional, que estão dispostos na sociedade (p. 189). Nas palavras de Machado:

"Poder este que intervém materialmente, atingindo a realidade mais concreta dos indivíduos - o seu corpo - e que se situa ao nível do próprio corpo social, e não acima dele, penetrando na vida cotidiana e por isso podendo ser caracterizado como micro-poder ou sub-poder" (p. 189).

Dessa forma, as relações de poder também estão presentes fora do âmbito estatal, de modo que o poder perpassa toda a estrutura social, o que faz com que todos estejam sujeitos à sua influência (p. 191). Diante disso, Foucault entende que a despeito da perspectiva negativa, que traduz o poder em repressão e dominação, há uma concepção positiva, no sentido de que o poder é produtivo e transformador. Exemplo desta produção consiste no indivíduo e o conhecimento que dele se pode ter, o que concretiza o poder como produtor do saber (p. 193).

Da mesma forma, Machado também enfatiza a noção foucaultiana de que o saber é marcado por aspectos políticos, afinal, tem sua gênese nas relações de poder. Assim, saber e poder se alimentam reciprocamente, de modo que não há relação de poder sem a afirmação de um saber, ao passo que 
o saber, por sua vez, é responsável por construir novas relações de poder (p. 199).

Em interlocução com esses conceitos, é interessante observar que o saber de Simão Bacamarte possuía ligação intrínseca com seu poder, visto que o cientista desenvolveu uma teoria, obteve meios legais para recolher pessoas à Casa Verde a fim de comprová-la, sendo certo que a partir destas experiências elaborou outra hipótese. Ou seja, o saber originário do psiquiatra possibilitou o exercício do poder, que, por sua vez, ampliou seu saber.

De acordo com Roberto Gomes, escritor e antigo professor de Filosofia da Universidade Federal do Paraná, no conto O Alienista Simão Bacamarte ocupa o lugar de fala da medicina psiquiátrica, que é tratada como exercício de poder (Gomes, 1993, p. 147). O autor chama atenção para o fato de que a postura do médico transcende as classificações e teorias a respeito da loucura, de modo que sua dedicação à ciência desencadeia um poder que exerce influência direta na dinâmica social da população itaguaiense (p. 148).

Assim, Gomes sustenta que a natureza da loucura não é o tema central do conto e para atestar seu pensamento, estrutura o texto em três momentos distintos. Inicialmente, antes da intervenção do alienista, não existiam loucos em Itaguaí. Em seguida, instaurado seu trabalho, surge uma "torrente de loucos" na cidade. Ao final, o cientista constata que ele seria o único alienado, e se retira para a Casa Verde. Essa fragmentação permite ao escritor afirmar que o médico e o seu discurso são fatores capazes de produzir a loucura (p. $150)$.

Com isso, Gomes demonstra que o cerne da obra não é propriamente a ciência, mas o poder da ciência (p. 153), de modo que Machado de Assis está

“além de seu século não apenas por questionar a concepção racionalista e positivista de ciência, mas por questionar o poder de todo e qualquer saber que pretenda apresentar-se como rigorosamente objetivo e com pretensões universais" (p. 153). 
Este poder científico é tão absoluto a ponto de trazer uma série de imunidades e privilégios ao alienista (p. 158), que se vê como sujeito legítimo para recolher aqueles que, a seu juízo, seriam ensandecidos. Outro exemplo que marca a posição de superioridade de Bacamarte está presente em seu discurso, que traça o distanciamento do médico em relação aos membros do povo:

“(...) Não dou razão dos meus atos de alienista a ninguém, salvo aos mestres e a Deus (...) Poderia convidar alguns de vós, em comissão dos outros, a vir ver comigo os loucos reclusos; mas não o faço, porque seria dar-vos razão do meu sistema, o que não farei a leigos (...)" (Gledson, 2015, p. 61).

Neste universo, os únicos capazes de opinar são os mestres, que por sua vez são cientistas, e Deus, que não costuma intervir em tais embates, como sublinha Gomes (p. 158). Dito de outro modo, na perspectiva apresentada, o povo não tem voz, apesar de sofrer diretamente as consequências do poder da ciência.

Além disso, é importante destacar que todas as camadas da população de Itaguaí foram contempladas nas suposições do Alienista. O Padre Lopes foi recolhido, o que representa a prevalência do poder frente à teologia (p. 157). Da mesma forma, o presidente da Câmara dos Vereadores não escapou à Casa Verde, de modo que até a figura de representação do legislativo da cidade dobrou-se à autoridade da ciência. Não havia limite ao poder do psiquiatra, que chegou ao ponto de aprisionar quatro quintos dos habitantes da cidade de uma vez, e depois de soltá-los, em razão de mudança na sua teoria, dedicou-se a recolher os demais que não haviam se enquadrado nos requisitos iniciais da loucura.

Não sem motivos, Simão recebeu o sobrenome Bacamarte, antiga arma de fogo. O personagem representa um alerta para os devotos do saber e do poder. Como conclui Gomes, não se deve desatentar para o fato de que nenhum poder é inocente, e deve ter contestada a sua razão (p. 153). 


\subsection{O Poder da Norma e o Abuso do Poder}

Entre as definições existentes para a palavra norma, o novo dicionário Aurélio apresenta três conceituações interessantes. Em primeiro lugar, norma seria "aquilo que se estabelece como base ou medida para a realização ou a avaliação de alguma coisa", significaria também "princípio, preceito, regra, lei", ou “modelo, padrão" (Holanda, 2003, p. 1.415). A partir destas acepções, será desenvolvido o conceito de norma jurídica para posteriormente traçar um paralelo com a norma buscada pelo Alienista, que visava estabelecer os limites entre a razão e a loucura (Gomes, 1994, p. 149).

Miguel Reale ensina que a norma jurídica consiste em uma estrutura composta por proposições que enunciam formas de organização ou conduta, a serem seguidas de forma obrigatória (Reale, 2014, p. 95). Para ele, não é apenas o formalismo que tem importância, pois a regra jurídica só pode ser compreendida de forma abrangente levando-se em consideração “(...) uma classe de fatos segundo uma ordem de valores" (p. 104). Além disso, para que seja legitimamente obrigatória é preciso que a norma jurídica observe requisitos de validade, que se desdobram em validade formal, social e ética (p. 105).

A validade formal é entendida como sinônimo de vigência. Para a vigência da lei é imperioso que seja emanada do órgão competente (p. 107), verse sobre assunto de sua atribuição e atenda os trâmites legais para compor o ordenamento jurídico (p. 110).

Já a validade social corresponde à eficácia, que diz respeito ao momento posterior à elaboração da norma jurídica, aquele no qual a conduta humana será praticada. Por esse motivo, a eficácia possui caráter experimental, e consiste na forma pela qual a coletividade reage à lei criada (p. 112). Uma vez reconhecida pela sociedade, a regra passa a ser incorporada de forma 
espontânea, já que as pessoas se identificam com os valores nela inscritos (p. 114).

Por último, Reale entende que a validade ética é o fundamento da norma, que se traduz no valor ou finalidade que se busca por meio dela. Em outros termos, é a razão de sua existência no mundo jurídico (p. 115).

Em síntese, a norma jurídica enquanto tal apresenta vigência, eficácia, fundamento e obrigatoriedade. Enquadra-se, portanto, na definição, anteriormente apresentada, de norma como a regra, a lei. Assim, por ser obrigatória, cria relações de poder.

No conto, o Alienista dedica-se a buscar a norma que estabeleça os limites entre a razão e a insânia (Gomes, 1994, p. 149). Neste contexto, a palavra norma possui a acepção de modelo, padrão, visto que o médico pretende alcançar o padrão da loucura, e consequentemente, da normalidade, de modo a traçar distinções objetivas em relação ao comportamento humano. Mais uma vez, a norma cria relações de poder, pois é a partir dela que Simão Bacamarte vai realizar seus recolhimentos à Casa Verde.

Compreendida a autoridade da norma, faz-se necessário verificar as diferenças entre a discricionariedade e a arbitrariedade na conduta de quem a aplica, a fim de reconhecer as situações nas quais resta caracterizado o abuso do poder.

José dos Santos Carvalho Filho ensina que o poder discricionário consiste em prerrogativa concedida aos agentes administrativos de elegerem, por meio de um juízo de conveniência e oportunidade, dentro das condutas possíveis, aquela que melhor atende ao interesse público (Filho, 2016, p. 110). Trata-se, assim, de uma liberdade dentro dos limites permitidos em lei.

Ainda, o autor destaca que para que a discricionariedade seja exercida consoante a legalidade é preciso verificar se a conduta adotada pelo agente público é adequada à finalidade disposta na lei, bem como averiguar os motivos que ensejaram tal postura (p. 110). Por outro lado, quando o agente 
atua fora dos limites legais, age de forma arbitrária, caracterizando o abuso de poder (p. 107).

De acordo com Anna Mayra Araújo Teófilo, Machado de Assis denuncia a questão da discricionariedade e da arbitrariedade no conto, exemplificada a partir do seguinte trecho (Teófilo, 2013, p. 9):

"A Câmara permite a constituição da casa verde a partir de uma atitude discricionária; mas, a exacerbada crueldade de Simão Bacamarte utilizada em seus experimentos e a "cláusula pétrea" na lei que proíbe a internação de vereadores, nada mais são do que manifestações de arbitrariedade" (p. 9).

O Alienista se ocupava de uma atividade pública que consistia em recolher e estudar as pessoas portadoras de sofrimento mental, ou seja, atuava como agente público exercendo papel importante na área da saúde de Itaguaí. Neste contexto, salta aos olhos as razões arbitrárias, atribuídas pelo médico como causas da loucura (p. 9), que ensejavam o recolhimento das pessoas. Diante dos motivos despropositados para justificar os casos de insanidade, a conduta do psiquiatra representava o abuso do poder.

Neste cenário, como observa Dino Del Pino, o foco da tensão no conto é o medo, seja ele da reclusão, da segregação social ou da prisão arbitrária (Pino, 2015, p. 170). O autor esclarece que este medo decorre do “(...) poder arbitrário que tem Simão para prender quem quer que seja (...)” (p. 171).

Pino entende que o conto sinaliza que a ciência nem sempre é aquilo que aparenta, de modo que a atuação irresponsável de seus agentes pode ser fonte de medo das pessoas (p. 172). Esta lógica também se aplica à ciência do Direito, que não passou isenta de críticas na narrativa. Para Anna Mayra Araújo Teófilo, “(...) o Direito nos é revelado não como uma atitude de realizar o que é certo entre as pessoas, mas, como uma forma arbitrária de poder (das minorias), fundamentada na racionalidade que frustra sonhos, desejos, aspirações (...)” (Teófilo, 2013, p. 9). 
As reflexões destacadas permitem afirmar que o conto de Machado de Assis retrata o abuso de poder e, simultaneamente, expõe a gravidade de suas consequências na esfera social. Para evitar que a vida imite a arte, hoje, a Constituição em vigor contém em seu texto uma série de direitos e garantias fundamentais, que funcionam como instrumentos para enfrentar eventuais arbitrariedades cometidas contra os cidadãos.

\subsection{Os Direitos e as Garantias Fundamentais como Mecanismos para Combater Arbitrariedades}

Robert Alexy, jurista e filósofo alemão, entende que para compreender o significado das normas de direitos fundamentais no sistema jurídico é preciso levar em consideração dois fatores, a dizer a fundamentalidade formal e a fundamentalidade substancial. O primeiro quesito decorre da posição destacada que as normas de direito fundamental ocupam no ordenamento, configurando “(...) direitos que vinculam diretamente o legislador, o Poder Executivo e o Judiciário" (Alexy, 2015, p. 520). Já em relação ao segundo aspecto, o autor sustenta que tais normas são substanciais porque a partir delas “(...) são tomadas decisões sobre a estrutura normativa básica do Estado e da sociedade" (p. 522).

A partir desta tese, as normas de direitos fundamentais desempenham um papel central no sistema normativo (p. 523). Na medida em que vinculam todos os poderes em que se desdobra o Estado, funcionam como mecanismo para evitar arbitrariedades, delimitando a relação entre um titular de um direito fundamental e um não titular (p. 528), além de refletirem os valores buscados para a comunidade a que se destina.

No plano da doutrina brasileira, José Afonso da Silva sustenta que a expressão "direitos fundamentais do homem" designa princípios que informam a ideologia política do ordenamento jurídico, bem como as prerrogativas para a 
convivência digna, situações sem as quais o ser humano não se realiza, tampouco sobrevive; além disso, representa a limitação do poder estatal imposta pela soberania popular (Silva, 2015, p. 180). Uma vez existentes esses direitos, faz-se necessário que sejam assegurados, o que ocorre por meio das garantias fundamentais. Nas palavras do autor:

“(...) como notara Maurice Hauriou, não basta que um direito seja reconhecido e declarado, é necessário garanti-lo, porque virão ocasiões em que será discutido e violado. Ruy Barbosa já dizia que uma coisa são os direitos, outra as garantias, pois devemos separar "no texto da lei fundamental, as disposições meramente declaratórias, que são as que imprimem existência legal aos direitos reconhecidos, e as disposições assecuratórias, que são as que, em defesa dos direitos, limitam o poder. Aquelas instituem os direitos; estas, as garantias (...)" (p. 188).

Assim, as garantias constitucionais representam imposições que limitam a atuação do poder público, de modo a assegurar ou reestabelecer a observância dos direitos fundamentais (p. 191).

No âmbito destes direitos, Fábio Konder Comparato aborda a distinção desenvolvida pela doutrina jurídica alemã em relação aos direitos humanos a fim de reconhecer a vigência efetiva de tais normas na sociedade (Comparato, 2005, p. 57). Neste contexto, os direitos fundamentais são “(...) os direitos humanos reconhecidos como tais pelas autoridades às quais se atribui o poder político de editar normas (...)" (p. 57), ou seja, é o direito positivado na Constituição e nas leis. Dessa forma, o reconhecimento formal, por parte de autoridade competente, dos direitos humanos, garante maior segurança às relações sociais (p. 58). Ocorre que a mera positivação consiste em fundamento simplório para a constituição de tais direitos, visto que o Estado concentra o poder de criá-los, alterá-los e, até mesmo, suprimi-los (p. 58). Por esse motivo, Comparato afirma que se faz necessário buscar também outro fundamento para a vigência dos direitos humanos, que seria

“(...)a consciência ética coletiva, a convicção, longa e largamente estabelecida na comunidade, de que a dignidade da condição humana exige o respeito a certos bens 
ou valores em qualquer circunstância, ainda que não reconhecidos no ordenamento (...)" (p. 59).

Dessa forma, reconhecer os direitos humanos como essenciais à vida digna, ainda que não dispostos nas leis escritas, também é forma de combater arbitrariedades perpetradas pelo Estado.

Ao analisar a Constituição brasileira de 1988, atualmente em vigor, José Afonso afirma que ela instituiu uma série de garantias dos direitos fundamentais da pessoa humana, além de fornecer os remédios constitucionais, que funcionam como instrumentos disponibilizados aos indivíduos para corrigir ilegalidades, bem como enfrentar o abuso de poder (Silva, 2014, p. 288). Compreende-se que o texto constitucional atribuiu maior relevo aos direitos e garantias fundamentais a partir da disposição que determina a aplicação imediata de suas normas definidoras, nos termos do art. $5^{\circ} \S 1^{\circ}(\mathrm{p}$. 288). No mesmo sentido, Ingo Sarlet sustenta que este artigo evidencia o status jurídico especial atribuído a estes dispositivos (Sarlet, 2015, p. 68).

Entre os direitos e garantias fundamentais inscritos no Título II da Constituição Federal, segundo a abordagem de José Afonso (Silva, 2015, p. 417-419), destaca-se, para os fins deste trabalho, a liberdade de ação geral, que apresenta como garantia o artigo $5^{\circ}$, inciso II, que prescreve "ninguém será obrigado a fazer ou deixar de fazer alguma coisa senão em virtude de lei”, o que está ligado intrinsecamente à finalidade da lei. Além disso, o direito previsto no inciso IX deste mesmo artigo enuncia que "é livre a expressão da atividade intelectual, artística, científica e de comunicação (...)" e apresenta como garantias a desnecessidade de licença e a independência quanto à censura (p. 417), que configuram concepções vinculadas à liberdade de pensamento, direito essencial ao Estado Democrático. Ainda, há que se ressaltar o direito à atuação democrática dos poderes públicos (p. 419), cuja garantia encontra-se prevista no inciso XXXIV, segundo o qual "são a todos assegurados, 
independentemente de pagamento de taxas: a) o direito de petição aos Poderes Públicos em defesa de direitos ou contra ilegalidade ou abuso de poder (...)”.

Não basta, portanto, a exigência prévia de lei que estabeleça as condutas obrigatórias e as proibições individuais para nascer o estado democrático de direito. Da mesma forma, a livre expressão e as demais liberdades constitucionais, por si, não são suficientes para evitar as injustiças e a opressão. Entretanto, a partir do momento em que existe a possibilidade de recorrer ao poder público a fim de defender os direitos fundamentais e denunciar os excessos cometidos pelas autoridades que o representam, abre-se uma perspectiva que não se limita ao combate das arbitrariedades praticadas, mas garante a prevalência do interesse público, que é o estrito cumprimento do texto constitucional, em vigor devido à soberania popular. 


\section{Capítulo III - Os Direitos e as Garantias Fundamentais na Constituição de 1988 e a Interpretação do Mundo das Leis}

\section{1 "Se um homem era avaro ou pródigo ia do mesmo modo para a Casa Verde; daí a alegação de que não havia regra para a completa sanidade mental" - A Questão da Legalidade.}

Em razão de sua importância para o funcionamento congruente do estado democrático de direito, o princípio da legalidade está presente em diversos dispositivos da Constituição Federal brasileira. Entre eles, destaca-se o art. $5^{\circ}$, inciso II, que funciona como diretriz da conduta social dos indivíduos, pois dispõe que "ninguém será obrigado a fazer ou deixar de fazer alguma coisa senão em virtude de lei”, além do art. 37, que prescreve a legalidade como um dos elementos centrais da Administração Pública.

No que se refere à legalidade da Administração, Gomes Canotilho entende que vigoram dois princípios fundamentais, quais sejam a supremacia da lei e a reserva legal (Canotilho, 2010, p. 256). De acordo com o autor:

\footnotetext{
“(...) num Estado democrático-constitucional a lei parlamentar é, ainda, a expressão privilegiada do princípio democrático (daí a sua supremacia) e o instrumento mais apropriado e seguro para definir os regimes de certas matérias, sobretudo dos direitos fundamentais e da vertebração democrática do Estado (daí a reserva de lei)” (p. 256).
}

Isto significa que a lei elaborada pelo poder legislativo é superior e prevalece diante dos atos da Administração Pública, sejam eles regulamentos, atos administrativos ou instruções (p. 256). Por esse motivo, a Administração não pode praticar atos contrários às leis, tampouco restringir direitos, liberdades e garantias sem amparo ou autorização legal para este fim (p. 256).

Dessa forma, faz sentido sustentar que os princípios da supremacia da lei e da reserva legal vinculam o poder executivo ao ordenamento jurídico constitucional pátrio (p. 256), na medida em que cabe ao poder legislativo 
elaborar as leis em sentido estrito. Em última análise, o que justifica esta subordinação é a soberania popular, inscrita no artigo $1^{\circ}$, parágrafo único do texto constitucional, que determina "todo poder emana do povo, que o exerce por meio de representantes eleitos ou diretamente, nos termos desta Constituição".

Compreendida a importância e o alcance da lei, deve-se atentar para que não seja utilizada como ferramenta voltada para amparar condutas incompatíveis com o espírito constitucional vigente. Afinal, práticas ilegais e arbitrárias por vezes verificadas no cotidiano contribuem para o crescimento do ceticismo da sociedade em relação ao Direito como mecanismo eficaz para ditar as regras e os institutos destinados à construção do estado democrático.

Neste sentido parece enveredar o conto de Machado de Assis, na medida em que a obra apresenta as ações dos personagens respaldadas por instrumentos do universo jurídico, e, apesar disso, o que se destaca é o império da arbitrariedade. Inicialmente, quando o Alienista decide cuidar da patologia cerebral da população de Itaguaí, pede autorização à Câmara dos Vereadores. Assim, a licença votada e permitida pelo poder legislativo em nível local é o primeiro marco concreto da roupagem jurídica constante na narrativa.

Adiante, quando se intensificam os recolhimentos à casa de Orates, o barbeiro Porfírio e mais trinta pessoas levam uma representação aos vereadores a fim de fechá-la, o que foi prontamente negado. Mais uma vez, a petição redigida expõe a natureza jurídica que acompanha a história.

Logo em seguida, Sebastião Freitas, vereador dissidente, reservou-se " $o$ direito de pedir pelos meios legais a redução da Casa Verde" (Gledson, 2015, p. 59). Neste trecho, a legalidade aparece de forma explícita, visto que a fala do político sugere que o Direito, no contexto do conto, possuía instrumentos capazes de frear as arbitrariedades autorizadas pelo legislativo e exercidas pelo médico. 
No curso dos confinamentos, qualquer comportamento passou a ser considerado loucura, de modo que "se um homem era avaro ou pródigo ia do mesmo modo para a Casa Verde; daí a alegação de que não havia regra para a completa sanidade mental” (p. 69). Ao contrário do perfeito equilíbrio das faculdades mentais, impossível de regulamentação, José Afonso da Silva afirma que, no âmbito do Estado de Direito, a ideia de justiça repousa na constatação de que a ciência jurídica estabelece normas gerais para solucionar os conflitos (Silva, 2014, p. 488).

Com o objetivo de compreender a dimensão e o papel do Direito frente aos excessos descritos no conto, é pertinente observar a distinção entre a segurança do Direito e a segurança jurídica, traçada por José Afonso. Em relação àquela, o autor ensina:

\footnotetext{
“A segurança do Direito é a que exige a positividade do Direito, e é neste contexto que a segurança se entronca com a constituição, na medida em que esta constitui o fundamento de validade do direito positivo. (...) é a constituição que condiciona não só sua validade, mas também certas exigências a respeito de seu conteúdo (...) e é também aqui que a segurança pode harmonizar-se com o valor do justo, na medida em que a constituição tem por missão assegurar a vigência e a eficácia do princípio da dignidade da pessoa humana, em que se centram todas as demais manifestações dos direitos fundamentais do homem" (p. 487).
}

Dessa forma, José Afonso afirma que a positividade por si não é capaz de assegurar o Direito justo, visto que há exemplos de ordenamentos jurídicos positivos injustos, é o caso daqueles que fundam os sistemas autoritários (p.487). Por esse motivo, conclui que a segurança legítima do Direito é a que significa garantia de todos perante as arbitrariedades e injustiças (p. 488). Assim, partindo-se deste conceito é possível sustentar que a Constituição brasileira de 1988 consiste não apenas em direito positivado como forma de atestar a segurança do Direito, mas em instrumento legítimo capaz de garantir a justiça, visto que apresenta extenso rol de direitos e garantias a serem utilizados na proteção de todos que se encontram no território nacional. 
Em decorrência da positividade do Direito surge a garantia da segurança jurídica (p. 488). Quanto ao conceito, nos termos da Constituição, Jose Afonso ensina que pode ser compreendido em sentido amplo ou em sentido estrito:

No primeiro ela assume o sentido geral de garantia, proteção, estabilidade de situação ou pessoa em vários campos (...). Em sentido estrito a segurança jurídica consiste na garantia de estabilidade e de certeza dos negócios jurídicos, de sorte que as pessoas saibam de antemão que, uma vez envolvidas em determinada relação jurídica, esta se mantém estável mesmo se se modificar a base legal sob a qual se estabeleceu (p. 489).

Todas essas definições ditam a interpretação do mundo das leis, de modo que contribuem para a edificação de um ordenamento constitucional capaz de frear as tentativas de abuso, seja pelo Estado, seja pelo particular.

De volta à narrativa machadiana, sob a ótica da legalidade, o ápice do conto aparece no momento em que o Alienista envia um ofício à Câmara dos Vereadores no qual informa que sua teoria das moléstias cerebrais estava equivocada e, por esse motivo, soltaria aqueles que estavam na Casa Verde para dar lugar aos que se encontravam nas novas condições características da loucura. Em resposta, os vereadores legislaram autorizando provisoriamente o médico a realizar os recolhimentos, com a ressalva de que a Câmara poderia fechar a instituição por motivos de ordem pública; por fim, estabeleceram uma cláusula que proibia Simão Bacamarte de interná-los, fato que evidenciou ao médico que não padeciam do perfeito equilíbrio, o que lhes garantiu a liberdade, e simultaneamente, expôs todas as arbitrariedades presentes na narrativa, seja na postura dos representantes eleitos, como nas teorias oscilantes do Alienista.

A caricatura da arbitrariedade fica ainda mais evidente no momento em que o barbeiro Porfírio é preso pela segunda vez. Ao contrário da primeira oportunidade, em que liderou a rebelião contra a Casa Verde, posteriormente se recusou a realizar outro movimento contra o Alienista, ainda que apoiado pelos "principais da vila" (Gledson, 2015, p. 76), sob o argumento de que " $a$ 
ambição o levara da primeira vez a transgredir as leis, mas que ele se emendara (...)” (p. 76). Como a teoria da loucura havia mudado, Porfírio enquadrou-se na nova concepção, pois se mostrou um sujeito virtuoso, e foi novamente metido na instituição, levando-o à célebre frase que intitula esta monografia, “Preso por ter cão, preso por não ter cão!” (p. 76).

Pelos episódios descritos, o conto ilustra de que forma as leis e o Direito podem ser utilizados como meio de institucionalização da violência a partir de um cenário no qual impera a falsa legalidade, responsável pelos abusos e insegurança constantes na vida dos itaguaienses. Assim, a interpretação da narrativa permite que o leitor identifique semelhanças com situações cotidianas, de modo que possa lançar mão da Constituição vigente com o intuito de prevenir ou repreender todo excesso que importe violação aos direitos humanos fundamentais.

\section{2 "O alienista, sabendo da extraordinária inconsistência das opiniões desse vereador, entendeu que era um caso patológico, e pediu-o" - A Questão da Liberdade de Expressão.}

Entre os direitos e garantias fundamentais inscritos no rol do artigo $5^{\circ}$ da Constituição Federal encontra-se, no inciso IV, a liberdade de pensamento. Trata-se de pressuposto estrutural para o desenvolvimento e perpetuação do Estado democrático.

Em seu Tratado Teológico-Político, Baruch Espinosa sustenta que para preservar a paz do Estado é imprescindível assegurar a liberdade de opinião (Aurélio \& Spinoza, 2008, p. 309). Para o filósofo, nenhum soberano é capaz de impedir que o homem pense e julgue de forma singular determinado acontecimento (p. 301). Justamente pela impossibilidade de renunciar aquilo que é essencialmente humano, o autor entende que 
“jamais será possível, numa comunidade política, tentar sem resultados funestos que os homens, apesar de terem opiniões diferentes e até opostas, não digam nada que não esteja de acordo com aquilo que prescrevem as autoridades” (p. 301-302).

Espinosa entende que a existência de opiniões divergentes em relação à lei posta não representa ameaça ao Estado, visto que no estado democrático, que é aquele que mais se aproxima do estado de natureza, todos celebram um pacto por meio do qual se comprometem a sujeitar seus atos ao que for decido pela maioria (p. 308). Assim, é o comportamento humano, e não seu pensamento, que está sujeito às normas comumente fixadas, permitindo a convivência pacífica. Por isso, Espinosa alega que "quanto menos liberdade de opinião se concede aos homens, mais nos afastamos do estado mais parecido com o de natureza e, por conseguinte, mais violento é o poder" (p. 308).

Dois episódios no conto de Machado de Assis estão relacionados com a questão da liberdade de pensamento, e consequentemente, com a liberdade de expressão. No início da história, quando o Alienista desenvolve uma nova teoria sobre a loucura, Crispim Soares sugere sua divulgação por matraca, um dos meios de comunicação utilizados na época em que se passa a narrativa. Com o objetivo de elucidar o leitor a respeito do poder de persuasão desse recurso, o narrador cita o exemplo do vereador que contratou a matraca por meses e adquiriu a fama de perfeito educador de cobras e macacos sem nunca ter domesticado nenhum desses animais.

Nas entrelinhas, Machado trata de forma irônica o processo de formação da opinião pública, como aponta Ivan Teixeira (Teixeira, 2008, p. 155), de modo que a mera reprodução da notícia, ainda que inverossímil, é suficiente para que a população seja enganada pelo "uso oportunista da imprensa" (p. 155). A informação desacompanhada do pensamento crítico, curiosidade e verificação em outras fontes compromete o conhecimento dos fatos porque oferece apenas um de seus ângulos, que pode ser equívoco. O pensamento livre só é plenamente possível diante de informações verdadeiras e fontes 
confiáveis, sobretudo no cenário contemporâneo no qual as fake news (notícias falsas) são utilizadas diariamente como manobra das mentes pouco afeitas à leitura.

Outro evento pode ser citado para alertar os problemas da superficialidade. Quando o barbeiro Porfírio e mais trinta pessoas se reuniram para redigir e levar uma representação à Câmara, com o intuito de fechar a Casa Verde, afirmavam que o despotismo científico do médico estava ligado à ganância, pois os loucos não eram tratados de graça. Em resposta, o presidente da Câmara informou que o Alienista não receberia dinheiro pelos serviços prestados, o que deixou os revoltosos surpresos. Com o objetivo de perpetuar o movimento, Porfírio lança mão de uma metáfora para avivar seus companheiros:

"O barbeiro, depois de alguns instantes de concentração, declarou que estava investido de um mandato público, e não restituiria a paz a Itaguaí antes de ver por terra a Casa Verde, - "essa Bastilha da razão humana", - expressão que ouvira de um poeta local, e que ele repetiu com muita ênfase. Disse, e a um sinal todos saíram com ele" (Gledson, 2015, p. 58).

O efeito da retórica transcendeu os rebeldes para atingir Sebastião Freitas, vereador que mudou de opinião ao ouvir a denominação utilizada por Porfírio para se referir à instituição. De acordo com Teixeira, a utilização da frase de efeito imita com humor a suposta eficácia dos clichês na comunicação popular (p. 167), responsáveis por encobrir o discurso vazio. Não basta, portanto, a Constituição Federal incluir, entre os direitos fundamentais, a livre manifestação do pensamento e o acesso à informação para que a expressão seja substancialmente livre. É necessário que se aprenda a reconhecer os artifícios da linguagem, o que se torna possível na medida em que o cidadão busca diferentes versões sobre determinado ocorrido.

O segundo episódio que suscita o debate da liberdade de expressão decorre do momento em que o vereador Sebastião Freitas foi recolhido ao 
hospício pelo Alienista, que "sabendo da extraordinária inconsistência das opiniões desse vereador, entendeu que era um caso patológico, e pediu-o" (Gledson, 2015, p. 69). Na verdade, o que chamou a atenção do médico foi o fato de o político ter, inicialmente, apoiado o presidente da câmara dos vereadores, que havia recusado a representação assinada por Porfírio e mais trinta pessoas com o fim de fechar a Casa Verde, em seguida, quando ouviu a expressão "Bastilha da razão humana", utilizada pelo barbeiro (p. 58), mudou de parecer, e, por fim, quando os vereadores avistaram, pelas janelas da câmara, a multidão e a tropa, pensaram que a situação havia sido controlada, razão pela qual votaram uma petição para pagar um mês de soldo aos dragões, "cujo denodo salvou Itaguaí do abismo a que o tinha lançado uma cáfila de rebeldes" (p. 63), afirmação dita por Sebastião Freitas. Esses eventos demonstram as contradições do vereador, que manifestava ideias diametralmente opostas em curto intervalo de tempo.

De acordo com Gilmar Ferreira Mendes, o direito de se comunicar livremente está interligado à sociabilidade do ser humano (Branco \& Mendes, 2015, p. 264). Neste contexto, o autor entende que a garantia constitucional da liberdade de expressão

\footnotetext{
"tutela, ao menos enquanto não houver colisão com outros direitos fundamentais e com outros valores constitucionalmente estabelecidos, toda opinião, convicção, comentário, avaliação ou julgamento sobre qualquer assunto ou sobre qualquer pessoa, envolvendo tema de interesse público, ou não, de importância e de valor, ou não" (p. 264).
}

Trata-se de esfera na qual o Estado não deve intervir, de modo que não é sua atribuição determinar quais opiniões merecem o estatuto de veracidade e devem ser vistas como aceitáveis (p. 265). Por outro lado, o texto constitucional contém dispositivos que determinam restrições à liberdade de expressão, que revelam que este direito, assim como os demais direitos fundamentais, não é absoluto. 
É o caso do artigo $5^{\circ}$, IV, segunda parte, que prescreve a vedação ao anonimato. Da mesma forma, o inciso $\mathrm{X}$ determina que "são invioláveis a intimidade, a vida privada, a honra e a imagem das pessoas, assegurado o direito a indenização pelo dano material ou moral decorrente de sua violação", o que intensifica o conflito casuístico entre a liberdade de expressão e os direitos da personalidade, como à honra, imagem e intimidade, visto que diante do caso concreto há argumentos jurídicos para tutelar os dois institutos. Para Fábio Carvalho Leite

"De nada adianta enaltecer o valor da liberdade de expressão (...) se qualquer dano à
honra, que já deveria ser esperado, é logo reconhecido como um limite àquele direito.
A facilidade com a qual um dano sofrido por conta de ofensas é considerado um
limite à liberdade de expressão coloca em dúvida a importância da liberdade de
expressão e, por fim, a concepção que se tem de democracia" (Leite, 2014, p. 395-
408).

Além disso, a liberdade de expressão não admite o discurso de ódio, definido por Anthony Lewis como "ataques virulentos a judeus, negros, muçulmanos, homossexuais ou membros de qualquer outro grupo" (Lewis, 2011, p. 187). Segundo Gilmar Mendes, o discurso de ódio constitui crime, visto que sempre devem prevalecer os princípios da dignidade da pessoa humana e da igualdade, nos termos do entendimento do Supremo Tribunal Federal (Branco \& Mendes, 2015, p 274).

Apresentadas tais ressalvas, necessárias para análise jurídica das opiniões de Sebastião Freitas, que culminaram em seu recolhimento, chega-se a conclusão que o vereador não praticou ofensa à honra do Alienista, tampouco produziu discurso de ódio, sendo certo que jamais fez uso do anonimato. Dessa forma, suas falas estariam amparadas pela liberdade de expressão nos termos da Constituição Federal de 1988, já que mesmo aqueles que apresentam opiniões oportunistas e contraditórias têm voz no estado democrático de direito. 


\section{3 "Desde que a Casa Verde começara a povoar-se tão extraordinariamente, viu crescerem-Ihe os lucros (...); mas o interesse particular, dizia ele, deve ceder ao interesse público": a dicotomia entre o Público e o Privado.}

De acordo com Luís Roberto Barroso, a noção contemporânea de interesse público divide o conceito em interesse público primário e interesse público secundário (Barroso, 2009, p. 69). O primeiro refere-se à justiça, à segurança, ao bem-estar social, ou seja, é aquilo que cabe ao Estado promover para atender aos anseios de toda a sociedade (p. 69), e deve pautar as relações jurídicas estabelecidas entre os particulares, entre estes e as pessoas de direito público e, também, entre elas (p. 71). Por outro lado, o interesse público secundário pertence à pessoa jurídica de direito público, é entendido como sinônimo de interesse do erário (p. 69).

Neste contexto, entre os princípios que regem a atuação estatal, destacase a supremacia do interesse público sobre o interesse privado, que prescreve que o Estado não pode atender exclusivamente aos interesses de determinada classe social. Nas palavras de José dos Santos Carvalho Filho:

\footnotetext{
"as atividades administrativas são desenvolvidas pelo Estado para benefício da coletividade. Mesmo quando age em vista de algum interesse estatal imediato, o fim último de sua atuação deve ser voltado para o interesse público (...)" (Filho, 2016, p. 84).
}

Por este motivo, o autor sustenta que uma vez existente o conflito entre o interesse público e o privado, deve prevalecer o primeiro (Filho, 2016, p. 84). Em consonância com este entendimento, manifestou-se o barbeiro Porfírio, visto que

\footnotetext{
"desde que a Casa Verde começara a povoar-se tão extraordinariamente, viu crescerem-lhe os lucros pela aplicação assídua de sanguessugas que dali lhe pediam; mas o interesse particular, dizia ele, deve ceder ao interesse público" (Gledson, 2015, p. 57).
} 
Ainda que se possa duvidar dos propósitos implícitos na fala do barbeiro, visto que sua declaração ocorreu justamente no dia em que foi recolhido à Casa Verde o Coelho, sujeito que trazia com ele uma demanda, é certo que o caso evidencia a dicotomia entre o público e o privado. Trata-se de um dos exemplos que ilustra este debate no conto.

É interessante perceber, como observa Dino Del Pino, que o próprio Simão Bacamarte apresenta duas dimensões: a pessoal e a pública (Pino, 2015, p. 157). Se por um lado o protagonista é o maior médico do Brasil, casa-se com uma viúva escolhida em razão de suas qualidades biológicas e dedica-se ao estudo da patologia cerebral (p. 158), simultaneamente, destaca-se no cenário público pelo tratamento dos loucos de Itaguaí, ignorados até então pelo poder público, de tal forma que se torna "o principal responsável pelo controle da coletividade" (p. 159).

No âmbito da distinção entre o espaço público e o privado, Barroso ensina que

\footnotetext{
“o espaço estritamente privado compreende o indivíduo consigo próprio, abrigado em sua consciência (intimidade) ou com sua família, protegido por seu domicílio (privacidade). O espaço privado, mas não reservado, é o do indivíduo em relação com a sociedade, na busca da realização de seus interesses privados, individuais e coletivos. E, por fim, o espaço público é o da relação dos indivíduos com o Estado, com o poder político, mediante o controle crítico, a deliberação pública e a participação política" (Barroso, 2009, p. 62).
}

$\mathrm{Na}$ medida em que o conto se desenvolve são delineados os espaços públicos e privados, que evidenciam as duas dimensões do médico. Já em relação ao interesse público e privado há uma zona de penumbra, pois se confundem nas determinações de Simão Bacamarte. Neste aspecto, vale lembrar que durante o período marcado pela coleta desenfreada da população de Itaguaí, o narrador alerta para a desconfiança gerada nos cronistas da época sobre as condutas do Alienista: 
"Alguns cronistas creem que Simão Bacamarte nem sempre procedia com lisura, e citam em abono da afirmação (...) o fato de ter alcançado da câmara uma postura autorizando o uso de um anel de prata no dedo polegar da mão esquerda, a toda pessoa que, sem outra prova documental ou tradicional, declarasse ter nas veias duas ou três onças de sangue godo. Dizem esses cronistas que o fim secreto da insinuação à câmara foi enriquecer um ourives, amigo e compadre dele; mas, conquanto seja certo que o ourives viu prosperar o negócio depois da nova ordenação municipal, não o é menos que essa postura deu à Casa Verde uma multidão de inquilinos; pelo que, não se pode definir, sem temeridade, o verdadeiro fim do ilustre médico" (Gledson, 2015, p. 69-70).

Ao contrário da imagem construída no conto, o episódio induz ao leitor a acreditar que o Alienista não era movido unicamente pela ciência, de forma que suas atitudes, muitas vezes incompreensíveis para o povo, dissimulavam uma finalidade privada, em que pese exercesse atividade voltada para o bemestar social. Com isso, Machado de Assis expõe o modo equivocado pelo qual a dicotomia entre o público e o privado se revela na sociedade. 


\section{Capítulo IV - O papel do Advogado}

\subsection{O Advogado Machadiano}

A presença de personagens do universo jurídico na obra de Machado de Assis não é eventual. Neste sentido, Cássio Schubsky e Miguel Matos, autores do livro Doutor Machado - o direito na vida e na obra de Machado de Assis, afirmam que "dos nove romances de Machado de Assis, seis têm protagonistas bacharéis em Direito. Ao todo, são oito bacharéis de relevo, dos quais seis advogados, além de um desembargador e um diplomata aposentado" (Matos \& Schubsky, 2008, p. 27).

Entre os seus principais romances, destacam-se Dom Casmurro e Memórias Póstumas de Brás Cubas, ambos narrados por bacharéis em Direito, com a peculiaridade de este último ter como narrador um defunto-bacharel ( $\mathrm{p}$. 150). Essa constatação oferece ao leitor elementos para que possa compreender a forma pela qual o Direito se apresenta na obra do escritor brasileiro.

Como observa Fábio Perin Shecaira, em Memórias póstumas Machado de Assis traça a caricatura do bacharel brasileiro, propenso à falsa erudição (Schecaira, 2019, p.21). É dessa forma que Brás Cubas descreve sua experiência na Universidade de Coimbra:

\footnotetext{
"Não digo que a Universidade me não tivesse ensinado alguma; mas eu decorei-lhe só as fórmulas, o vocabulário, o esqueleto. Tratei-a como tratei o latim: embolsei três versos de Virgílio, dois de Horácio, uma dúzia de locuções morais e políticas, para as despesas da conversação. Colhi de todas as coisas a fraseologia, a casca, a ornamentação, que eram para o meu espírito, vaidoso e nu, o mesmo que, para o peito do selvagem, são as conchas do mar e os dentes de pessoa morta" (Assis, 2012, p. 6667).
}

Com isso, Shecaira conclui que Brás Cubas foi um estudante de direito superficial, tumultuário e petulante, com poucos méritos acadêmicos (Shecaira, 2019, p. 54), o que é explicitado pelo próprio narrador personagem: 
"A Universidade esperava-me com as suas matérias árduas, e não sei se profundas; estudei-as muito mediocremente, e nem por isso pedi o grau de bacharel (...) No dia que a Universidade me atestou, em pergaminho, uma ciência que eu estava longe de trazer arraigada no cérebro, confesso que me achei de algum modo logrado, ainda que orgulhoso" (Assis, 2012, p. 60).

Dessa forma, Machado retrata, de forma crítica e irônica, a visão que possuía daqueles que concluíam a universidade, supostamente responsável por conferir qualificação profissional aos estudantes, inclusive os de Direito.

Já em Dom Casmurro, o narrador personagem Bento Santiago é advogado de formação, dado que se revela essencial para a leitura da obra. $\mathrm{Na}$ medida em que se desenvolve a narrativa, paira uma dúvida na cabeça do leitor, em razão das características e episódios narrados por Bentinho - Capitu teria se envolvido em um caso extraconjugal com Escobar?

De acordo com Luiz Henrique Calabresi, professor do Instituto Federal de Educação, Ciência e Tecnologia de São Paulo, este livro pode ser interpretado como um processo judicial de acusação (Calabresi, 2011, p. 189). Neste sentido, salienta que

“(...) a narrativa do romance é construída com uma retórica bastante sofisticada e persuasiva (...). Uma estratégia fundamental para convencer os leitores, que também podem ser entendidos como jurados; é o mascaramento da obra quanto processo judicial. Segundo este raciocínio, observamos que as menções à formação em Direito precisam necessariamente ser breves, como recurso de convencimento" (p. 192).

Assim, é construída a figura do advogado machadiano como aquele que através da retórica pretende convencer seu interlocutor, ainda que por meio de argumentos vazios, mascarados por palavras e expressões rebuscadas. Essa caracterização também se faz presente no conto $O$ Alienista.

A partir da nova teoria desenvolvida por Simão Bacamarte, segundo a qual a loucura consistiria no perfeito equilíbrio mental, esteve prestes a recolher à Casa Verde o advogado Salustiano, "em quem reconheceu um tal conjunto de qualidades morais e mentais, que era perigoso deixa-lo na rua" 
(Gledson, 2012, p. 75). Antes disso, contudo, um agente desconfiado da retidão do causídico decidiu fazer uma experiência: aconselhou um compadre “demandado por testamento falso" (p. 75) a contratá-lo e confessar que havia, de fato, cometido o crime. Ao contrário das expectativas do Alienista, o advogado

“(...) estudou os papéis, arrazoou longamente, e provou a todas as luzes que o testamento era mais que verdadeiro. A inocência do réu foi solenemente proclamada pelo juiz, e a herança passou-lhe às mãos" (p. 75).

Graças a este comportamento, o advogado livrou-se da prisão dos alienados. Mais uma vez, a retórica mostrou-se inseparável do jurisconsulto, que apresentou, também, posturas questionáveis. Em outras palavras, o advogado machadiano é alguém perfeitamente desequilibrado.

\subsection{O Advogado como Protagonista na Defesa do Regime Democrático}

Se na literatura machadiana identifica-se a figura do advogado nos mais variados personagens, é certo que fora dos livros, na vida cotidiana, este detém o papel de protagonista na defesa do regime democrático. Isso ocorre porque, como entende José Roberto de Castro Neves, os advogados são os conhecedores e guardiães das normas, de modo que sem eles, o sistema se fragiliza (Neves, 2018, p. 233). O autor reconhece o papel de destaque da profissão da seguinte forma:

“(...) os advogados, desde tempos imemoriais, têm por missão garantir a ordem. (...) A experiência profissional será construída de frustrações num Estado despótico, corrupto e arbitrário. Eis por que os advogados sempre estiveram à frente da construção de um Estado de Direito, no qual se tutelam as garantias básicas dos cidadãos" (p. 265).

Em razão da importância do trabalho que desempenha, a Constituição Federal dispõe, em seu artigo 133, que "o advogado é indispensável à 
administração da justiça, sendo inviolável por seus atos e manifestações no exercício da profissão, nos limites da lei”. Em outras palavras, a advocacia é uma função essencial à justiça, visto que ao advogado cabe não apenas a busca pela prevalência do direito alheio frente às arbitrariedades, como também a luta contínua para a perpetuação do estado democrático de direito.

Com o objetivo de tornar ainda mais evidente a proeminência do papel do advogado, cumpre evidenciar no que consiste o estado democrático de direito. De acordo com José Afonso da Silva, a concepção mais recente deste modelo de estado indica que é aquele que possui legitimidade justa, responsável por fundar uma sociedade democrática, em que o povo participa da tomada de decisões (Silva, 2015, p. 122). A democracia que nele se desenvolve realiza

“um processo de convivência social numa sociedade livre, justa e solidária (...) pluralista, porque respeita a pluralidade de ideias, culturas e etnias e pressupõe assim o diálogo entre opiniões e pensamentos divergentes e a possibilidade de convivência de formas de organização e interesses diferentes da sociedade; há de ser um processo de liberação da pessoa humana das formas de opressão que não depende apenas do reconhecimento formal de certos direitos individuais, políticos e sociais (...)" (p. 121122).

Em síntese, cabe ao advogado combater os abusos a fim de preservar à legalidade, lançar mão das garantias constitucionais como mecanismos adequados para assegurar os direitos fundamentais, além de fiscalizar o estado, para que não se desvirtue de sua função pública, traduzida no interesse público. Assim, nas palavras de Castro Neves, "além de construir as bases da democracia, cabe ao homem - ao homem jurídico (...), em constante vigília, guardar e regar o Estado saudável, opondo-se às tantas ameaças que enfrenta" (Neves, 2018, p. 266). 


\section{Conclusão}

Pode-se sustentar que o Direito e a Literatura são formas complementares de compreender as relações sociais e o mundo. Do mesmo modo que se deve conhecer a História de um país, a fim de evitar que antigos equívocos sejam cometidos novamente, a literatura é um poderoso instrumento de críticas e denúncias da sociedade, ainda que estejam nas entrelinhas do texto. O Direito, por sua vez, estabelece normas e princípios jurídicos capazes de regular os vínculos existentes no cenário contemporâneo.

Neste contexto, torna-se interessante analisar as questões jurídicas que perpassam as narrativas, afinal, a leitura permite que se construa uma visão completa da história contada, o que é fundamental para que o leitor tenha a dimensão do que se pretende expor. Consequentemente, o estudo do direito na literatura possibilita que sejam traçados paralelos entre a ficção e a realidade, o que por sua vez, ocasiona uma releitura das situações cotidianas.

Através deste método, a presente monografia foi escrita com base no conto $O$ Alienista, de Machado de Assis, publicado pela primeira vez no século XIX. Ao analisar os elementos jurídicos constantes na história, tentou-se evidenciar em que medida as arbitrariedades e o abuso de poder podem ser nocivos para a sociedade, de modo que a população de Itaguaí chegou ao ponto de ter quatro quintos de seus membros enclausurados na Casa Verde. Ainda, de que forma o saber funciona como ferramenta para a institucionalização do poder, que é utilizado a serviço das teorias sobre a loucura, desenvolvidas pelo médico Simão Bacamarte.

Em cotejo com as garantias constitucionais existentes no Brasil república do século XXI, salta aos olhos no conto a falsa legalidade que ampara as condutas do Alienista. Supostamente respaldado na autorização da Câmara dos Vereadores, o médico constrói a Casa Verde e inicia o recolhimento desenfreado daqueles que define como loucos, sendo certo que a 
única preocupação dos vereadores era impedir que eles mesmos fossem internados, razão pela qual estipularam uma espécie de cláusula pétrea que não autorizava a internação dos edis. A constatação de que "não havia regra para a completa sanidade mental" acarretava na ausência de regras em geral, e na inevitável insegurança da população.

Além disso, o recolhimento do vereador Sebastião Freitas, que se deu em virtude das inconsistências de suas opiniões, revela verdadeira afronta à liberdade de expressão, direito fundamental assegurado expressamente na Constituição Federal de 1988, atualmente em vigor. Trata-se, portanto, de mais um caso de arbitrariedade denunciado no conto.

Adiante, o episódio do anel de prata, de uso obrigatório para determinadas pessoas, seria responsável por, supostamente, dissimular a finalidade privada do médico de beneficiar um amigo próximo que era ourives, e concomitantemente, aumentar o número de membros no asilo dos alienados. Com isso, o escopo unicamente científico do Alienista é questionado, em desabono ao princípio da prevalência do interesse público sobre o privado, tão presente no ordenamento jurídico pátrio do século XXI.

Depreende-se, através do conto machadiano ora analisado, a importância dos direitos e garantias fundamentais na vida social. Através de retratações caricatas chega-se a uma sociedade pautada no império da arbitrariedade, e paradoxalmente, adoecida por aquele que seria responsável por encontrar a cura da insanidade mental.

Com a missão de evitar que a realidade desenvolva semelhanças à narrativa, o advogado recebe o papel de protagonista na defesa do estado democrático de direito. Em razão do contato com o ordenamento jurídico e com o texto da constituição, é o responsável por lançar mão dos instrumentos disponíveis a fim de evitar abusos, bem como a deturpação do próprio sistema.

Em última análise, pode-se afirmar que a literatura enriquece o debate e a reflexão a respeito de temas jurídicos. A convicção de que há muito em 
comum nestas duas formas de ler o mundo, que transcende a mera edificação por meio de palavras, é o que motivou o presente trabalho. No fim, o jurista afeito à literatura tem acesso às mais variadas interpretações do que se convencionou denominar realidade, e como resultado, adquire incessantemente novos recursos para desempenhar suas atividades diante do caso concreto. 


\section{Bibliografia}

ALEXY, Robert. Teoria dos Direitos Fundamentais. $2^{\mathrm{a}}$ ed. São Paulo: Malheiros Editores, 2015. 669 p.

ASSIS, Machado de. Dom Casmurro. 17ª ed. São Paulo: Atica, 1986. 152 p.

ASSIS, Machado de. Memórias póstumas de Brás Cubas. 1ª ed. Rio de Janeiro: BestBolso, 2012. 239 p.

BARROSO, Luís Roberto. Curso de Direito Constitucional Contemporâneo: os conceitos fundamentais e a construção do novo modelo. São Paulo: Editora Saraiva, 2009. $451 \mathrm{p}$.

BRANCO, Paulo Gustavo Gonet; MENDES, Gilmar Ferreira. Curso de Direito Constitucional. 10ª ed. São Paulo: Editora Saraiva, 2015. 1470 p.

CALABRESI, Luis Henrique de Freitas. Dom Casmurro e a formação superior em Direito no Brasil no século XIX. Quaestio, Sorocaba, SP, v.14, n.1, p.173-193, maio 2012. Disponível em $\langle$ http://periodicos.uniso.br/ojs/index.php/quaestio/article/view/797>. Acesso em 9 de abril de 2019.

CANOTILHO, J.J. Gomes. Direito Constitucional e Teoria da Constituição. $7^{\mathrm{a}}$ ed. Coimbra: Almedina, 2010. 1522 p.

COMPARATO, Fabio Konder. A afirmação histórica dos direitos humanos. $4^{\mathrm{a}}$ ed. rev. e atual. São Paulo: Saraiva, 2005. 577 p. 
FILHO, José dos Santos Carvalho. Manual de Direito Administrativo. $30^{\mathrm{a}}$ ed. São Paulo: Atlas, 2016. 1553 p.

FOUCAULT, Michel. A arqueologia do saber. $8^{\text {a }}$ edição. Rio de Janeiro: Forense Universitária, 2017. 254 p.

FOUCAULT, Michel. A verdade e as formas jurídicas. Rio de Janeiro: Nau Editora, 2005. 158 p. Disponível em <http://files.philoethos.webnode.pt/200000028-67bb66814c/FOUCAULT\%20\%20A\%20verdade\%20e\%20as\%20formas\%20juridicas.pdf $>$

FOUCAULT, Michel; MACHADO, Roberto. Microfísica do poder. $16^{\mathrm{a}}$ ed. Rio de Janeiro: Graal, 2000 xxiii, 295 p.

GLEDSON, John. 50 Contos de Machado de Assis.14a ed. São Paulo: Companhia das Letras, 2015. 487 p.

GOMES, Roberto. O Alienista: loucura, poder e ciência. Rev. Sociol. USP, São Paulo, 5 (1-2):145-160, 1993, editado em nov. 1994). Disponível em < http://www.scielo.br/pdf/ts/v5n1-2/0103-2070-ts-05-02-0145.pdf>. Acesso em 20 de abril de 2019.

HESSE, Konrad. A força normativa da Constituição. Porto Alegre: Sergio Antonio Fabris 1991. 34 p.

HOLANDA, Aurélio Buarque, Novo dicionário Aurélio. Ed. Nova fronteira, 2003. 2120 p.

JUNQUEIRA, Eliane Botelho. Literatura e Direito: uma outra leitura do mundo das leis. $1^{a}$ ed. Rio de Janeiro: Letra Capital, 1998. 238 p. 
LEITE, Fábio Carvalho. Liberdade de Expressão e Direito à honra: novas diretrizes para um velho problema. In: Clèmerson Merlin Clève; Alexandre Freire. (org.). Direitos fundamentais e jurisdição constitucional: análise crítica e contribuições. $1^{\text {a }}$ ed. São Paulo: Revista dos Tribunais, 2014, v., p. 395-408.

LEITE, George Salomão; SARLET, Ingo Wolfgang; MORAES, Alexandre de. Direitos fundamentais e estado constitucional: estudos em homenagem a J. J. Gomes Canotilho. São Paulo: Revista dos Tribunais; Coimbra: Coimbra ed., 2009, 432 p.

LEWIS, Anthony. Liberdade para as ideias que odiamos. $1^{\mathrm{a}}$ ed. Editora Aracati, 2011. 248 p.

MACHADO, Roberto. Ciência e saber: a trajetória da arqueologia de Michel Foucault. $2^{\mathrm{a}}$ ed. Rio de Janeiro: Graal, 1982. 218 p.

MATOS, Miguel; SCHUBSKY, Cássio. Doutor Machado, o direito na vida e na obra de Machado de Assis. $1^{\text {a }}$ ed. São Paulo: Editora Lettera.doc, 2008. 375 p.

NEVES, José Roberto de Castro. Como os advogados salvaram o mundo. $1^{\mathrm{a}}$ ed. Rio de Janeiro: Nova Fronteira, 2018. 397 p.

OST, François. Contar a lei. $1^{\text {a }}$ ed. Rio Grande do Sul: Editora Unisinos, 2007. $461 \mathrm{p}$.

PEREIRA, Denise Manzi Frayze; KOSHIBA, Luiz. História do Brasil no contexto da história ocidental. $8^{\mathrm{a}}$ ed. São Paulo: Atual, 2003. 602 p.

PILATTI, Adriano. A Constituinte de 1987-1988: progressistas, conservadores, ordem econômica e regras do jogo. Rio de Janeiro: Lumen Juris: Ed. PUC-Rio, 2008, xvi, 334 p. 
PINO, Dino del. O Alienista: loucura, ciência e paródia. ANAMORPHOSIS-

Revista Internacional de Direito e Literatura, v.1, n.1, janeiro/junho 2015. Disponível em < http://rdl.org.br/seer/index.php/anamps/article/view/17/pdf_2>. Acesso em 20 de março de 2019.

REALE, Miguel. Lições preliminares de Direito. $27^{\mathrm{a}}$ ed. São Paulo: Saraiva, 2014. $391 \mathrm{p}$.

SARLET, Ingo Wolfgang. A eficácia dos direitos fundamentais. $12^{\mathrm{a}}$ ed. rev. e atual. Porto Alegre: Livraria do Advogado, 2015. 504 p.

SARLET, Ingo Wolfgang; MARINONI, Luiz Guilherme; MITIDIERO, Daniel Francisco. Curso de direito constitucional. São Paulo: Revista dos Tribunais, 2012. $1263 \mathrm{p}$.

SCHECAIRA, Fábio Perin. Direito e Literatura. $1^{\mathrm{a}}$ ed. Curitiba: Alteridade, 2019. $158 \mathrm{p}$.

SCHWARTZ, Germano André Doerderlein. A Constituição, a literatura e o direito. $1^{\mathrm{a}}$ ed. Porto Alegre: Livraria do Advogado, 2006. 85 p.

SILVA, José Afonso. Curso de Direito Constitucional Positivo. $38^{\mathrm{a}}$ ed. São Paulo: Malheiros Editores, 2015. 936 p.

SILVA, José Afonso. Teoria do Conhecimento Constitucional. $1^{\mathrm{a}}$ ed. São Paulo: Malheiros Editores, 2014. 1054 p.

SPINOZA, Benedictus de; AURÉLIO, Diogo Píres. Tratado teológicopolítico. $2^{\mathrm{a}}$ ed. São Paulo: Martins Fontes Paulista, 2008. 375 p. 
TEIXEIRA, Ivan Prado. Irônica invenção do mundo, uma leitura de O Alienista. Revista USP, São Paulo, n.77, p.149-169, março/maio 2008. Disponível em 〈http://www.revistas.usp.br/revusp/article/view/13663/15481 >. Acesso em 12 de março de 2019.

TEÓFILO, Anna Mayra Araújo. Direito, literatura e "O Alienista" de Machado de Assis. XXII Encontro Nacional do CONPEDI/Universidade Nove de Julho, São Paulo, 2013. Disponível em < http://www.publicadireito.com.br/artigos/?cod=8110eaeb55d8f5ed $>$. Acesso em 6 de maio de 2019. 